\title{
MONITORING COMPLIANCE WITH GOVERNMENTAL AND INSTITUTIONAL OPEN ACCESS POLICIES ACROSS SPANISH UNIVERSITIES
}

\author{
Seguimiento del cumplimiento de las políticas de \\ acceso abierto gubernamental $e$ institucional en \\ universidades españolas
}

Reme Melero, David Melero-Fuentes, and Josep-Manuel Rodríguez-Gairín
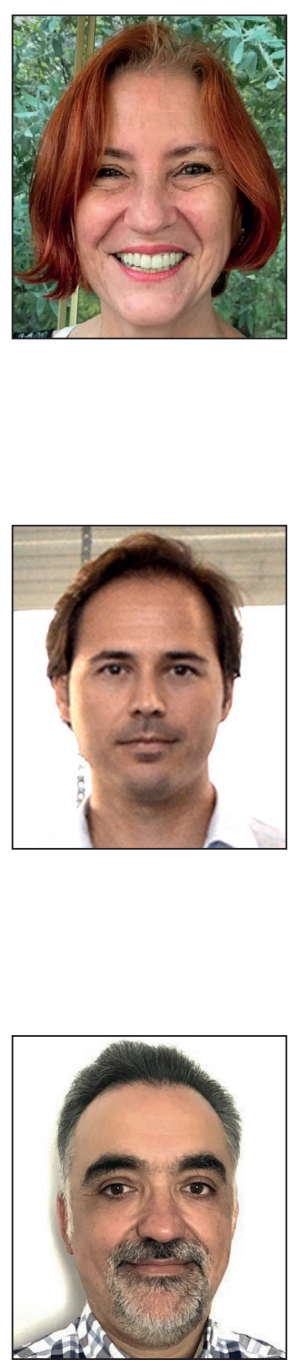

Remedios Melero, PhD in Chemical Sciences from the University of Valencia, is a researcher at the Institute of Agrochemistry and Food Technology, of the Higher Council for Scientific Research (CSIC) and editor of the scientific journal Food Science and International Technology. She is editor of the Directory of Open Access Journals (DOAJ). Member of the scientific committee of Redalyc and SCIELO Spain. Coordinator of the Spanish Open Access to Science working group, participates on a national project related to research data and open science. She is a member of the Maredata thematic network, and a partner in the Foster+ project (Facilitate Open Science Training for European Research) for the promotion of European open science policies and training in related topics. https://orcid.org/0000-0002-1813-8783

Consejo Superior de Investigaciones Cientificas (CSIC), Instituto de Agroquímica y Tecnología de Alimentos (IATA) Catedrático Agustín Escardino 7. 46980 Paterna (Valencia), Spain rmelero@iata.csic.es

David Melero-Fuentes, PhD in Documentation (European mention) from the Catholic University of Valencia San Vicente Mártir (UCV), is a professor and secretary of the Institute of Documentation and Information Technology (Indotei) at the same university. During his doctorate he was a beneficiary of a predoctoral stay of the UCV in the Department of Bibliometrics of the University of Vienna. Its main fields of activity are evaluation of research, informetrics, information retrieval and analysis of social networks.

https://orcid.org/0000-0002-4610-3000

Universidad Católica de Valencia San Vicente Mártir (UCV) Instituto de Documentación y Tecnologías de la Información (Indotei) Quevedo, 2. 46001 Valencia, Spain david.melero@ucv.es

Josep-Manuel Rodríguez-Gairín holds a PhD in Documentation from the University of Barcelona $(U B)$ and a lecturer in the School of Library and Information Sciences at the UB, where he also coordinates computer rooms and advises on technological aspects. He has carried out the infrastructure of projects such as Digital journals of librarianship and information science (Temaria); BiD journal: University texts of librarianship and documentation; Information matrix for the evaluation of journals (MIAR); Online resources to carry out research works (Alehoop); Directory of experts in information handling (EXIT); International registry of authors-Links to identify scientists (IraLIS), Chronology of Spanish Documentation (CroDoc), etc. He is a member of Ciepi, ThinkEPI and the technical council of the E-LIS repository. Founder of the Kronosdoc company, dedicated to the consultancy and development of documentary management programs.

http://orcid.org/0000-0001-8375-7911

Universitat de Barcelona, Facultat de Biblioteconomia i Documentació Melcior de Palau, 140. 08014 Barcelona, Spain rodriguez.gairin@ub.edu 


\begin{abstract}
Universities and research centers in Spain are subject to a national open access (OA) mandate and to their own OA institutional policies, if any, but compliance with these requirements has not been fully monitored yet. We studied the degree of OA archiving of publications of 28 universities within the period 2012-2014. Of these, 12 have an institutional OA mandate, 9 do not require but request or encourage OA of scholarly outputs, and 7 do not have a formal OA statement but are well known for their support of the OA movement. The potential OA rate was calculated according to the publisher open access policies indicated in Sherpa/Romeo directory. The universities showed an asymmetric distribution of $1 \%$ to $63 \%$ of articles archived in repositories that matched those indexed by the Web of Science in the same period, of which $1 \%$ to $35 \%$ were $\mathrm{OA}$ and the rest were closed access. For articles on work carried out with public funding and subject to the Spanish Science law, the percentage was similar or slightly higher. However, the analysis of potential OA showed that the figure could have reached $80 \%$ in some cases. This means that the real proportion of articles in OA is far below what it could potentially be.
\end{abstract}

\title{
Keywords
}

Open access; Compliance; Mandates; Monitoring open access policies; Potential open access; Spain; Universities; Science law.

\section{Resumen}

Las universidades y centros de investigación en España están sujetos a un mandato de acceso abierto (OA) nacional, de acuerdo con la Ley de la ciencia en su artículo 37, y con sus propias políticas institucionales de libre acceso, si las hubiese, pero todavía no existe un seguimiento regular del cumplimiento de estos requisitos. En este estudio se analiza el grado de depósito de las publicaciones de 28 universidades en el período 2012-2014. De éstas, 12 tienen un mandato institucional de OA, 9 recomiendan el depósito en OA de los resultados académicos, y 7 no tienen una declaración formal de OA, pero son conocidas por su apoyo a este movimiento. La ratio de OA potencial se calculó de acuerdo con las políticas de autoarchivo de las revistas, extraídas del directorio Sherpa/Romeo. Las universidades mostraron una distribución asimétrica en cuanto al depósito de los artículos, variando entre el $1 \%$ al 63\%, tomando como referencia los artículos indexados por la Web of Science en el mismo período. De éstos, entre $1 \%$ a 35\% estaban en OA y el resto en acceso restringido. El porcentaje de artículos depositados que declaraban tener una financiación de fondos estatales y por tanto sujetos a la Ley de la ciencia española, fue similar al obtenido cuando se consideró la producción total de cada una de las instituciones, o ligeramente superior. Sin embargo, el análisis del acceso abierto potencial mostró que la cifra podría haber alcanzado el $80 \%$ en algunos casos. Esto significa que la proporción real de artículos en acceso abierto está muy por debajo de lo que potencialmente podría ser.

\section{Palabras clave}

Acceso abierto; Cumplimiento; Mandatos open access; OA; Monitorización del acceso abierto; Políticas open access; Acceso abierto potencial; España; Universidades; Ley de la Ciencia.

Melero, Reme; Melero-Fuentes, David; Rodríguez-Gairín, Josep-Manuel (2018). “Monitoring compliance with governmental and institutional open access policies across Spanish universities". El profesional de la información, v. 27, n. 4, pp. 858-878.

https://doi.org/10.3145/epi.2018.jul.15

\section{Introduction}

"Open access literature is digital, online, free of charge, and free of most copyright and licensing restrictions" (Suber, 2004), so anyone can benefit from reading and using the research. There are two routes to achieving OA to scholarly publications: the green and the gold routes BOAI (2002). Gold OA means publication in journals that are freely accessible with or without article publishing charges (APCS). Green OA means publishing in a journal and self-archiving the published articles in an OA repository; the version that can be deposited depends on the publishers' posting policies and authors' rights.

Universities, research institutions and funders increasingly require open access to scholarly outputs. For example, the Research Councils UK (2014) require open access to peer-reviewed research articles resulting from projects funded by them, and allow embargoes to deposit between 6 and 12 months. The Higher Education Funding Council for England
(2014) also requires articles and conference proceedings to be openly available and deposited in an institutional or subject repository in order to be eligible for submission to the Research Excellence Framework (REF). This requirement began to be applied to journal articles and conference proceedings accepted for publication after 1 April 2016.

The Wellcome Trust (2005), the National Institute of Health (2008), the National Science Foundation (2015), the European Research Council (2007) and the H2020 program of the European Commission (2016) have OA policies whereby authors who receive funding from them are required to deposit their publications in a repository, and failure to comply may lead to withdrawal of funds.

The University of Liège (2007), which is a model for other institutions, bases the research evaluation exercise on the materials deposited in its repository. Harvard University (2008), the Massachusetts Institute of Technology (2009), the University of Southampton (Sale, 2006) and the Univer- 
sidade do Minho (2005) have also been pioneers in declaring $O A$ policies for their publications and establishing mechanisms to monitor self-archiving.

However, despite the implementation of regulations and policies that favor $\mathrm{OA}$, compliance with self-archiving in repositories is still far from 100\% (Swan et al., 2015). Even monitoring compliance is not an easy task, because it is sometimes difficult to determine the total scientific and academic output of a university, and to determine whether and where it is available in OA. As an approximation, Scopus and the Web of Science (WoS) are used to search papers published by an institution, though it is known and accepted that the results of the search do not include all publications. Current research information systems (CRIS) are another source of information on the scholarly outputs of a university. They contain information on the research projects that are underway and the metadata of the publications arising from them, and tend to be linked to and interoperable with the institutional repositories (Ribeiro; De-Castro; Mennielli, 2016). Therefore, the universities themselves are the most suitable agents for monitoring and ensuring that publications are deposited in the institutional repositories as part of an OA policy, thus avoiding dispersion of the work on several websites (Harnard, 2015).

The reasons for self-archiving may vary according to the area of work and the type of repository. According to the results of the PEER (Publishing and the Ecology of European Research) project (Spezi et al., 2013), the three reasons most identified by the authors for archiving in an institutional repository were "required by employer", "invited by the repository" and "invited by a librarian". For subject repositories, the reasons were "voluntarily", "invited by publisher" or "required by research funder". The PEER project also found differences between disciplines. Voluntary self-archiving is greater in the physical sciences, mathematics, social sciences and humanities than in biomedical sciences. Natural and health sciences prefer the gold road, whereas physics, mathematics, social sciences and humanities prefer the green road. Eger, Scheufen and Meierrieks (2015) reached the similar conclusions from a survey of authors from German universities.

Open access to scholarly publications favors visibility, increases the impact of research, increases the number of readers, and breaks economic barriers between countries and communities. However, in practice authors do not exercise their right and/or duty to self-archive, because of lack of knowledge of publisher policies on self-archiving, fear of infringing copyright, not knowing how to archive, not having time and not trusting the repositories (Frass; Cross; Gardner, 2014).

One way to overcome these obstacles is to establish an institutional policy that encourages self-archiving, acknowledges the support received by researchers and uses the material in repositories as a source for evaluating teaching staff. Indeed, the staff assessment policy at the University of Liège only takes into account what is archived in their institutional repository, even if it is under embargo or closed access (University of Liège, 2007).

\subsection{Previous findings regarding $O A$ papers online and OA policy compliance}

Several studies indicate the proportion of publications available in OA worldwide by countries and by disciplines. Björk et al. (2010) took a random sample of 1,837 articles published in 2008 and found that $20.4 \%$ were OA: $8.5 \%$ on publisher's websites and $11.9 \%$ on other websites. Archambault et al. (2013) reported that $43 \%$ of the articles published between 2004 and 2011 indexed in Scopus were OA: 33\% by the green road and the hybrid road (articles published in toll access journals but with optional OA by payment of an APC) and $10 \%$ by the gold road. Chen (2014), in a study of articles published in 2013 and indexed in Scopus, found that $37.8 \%$ were available in OA on journal websites, personal web pages, institutional repositories, social networks or other websites. Kahbsa and Giles (2014) used Google Scholar and Microsoft Academic Search applied mathematical methods to analyze all the articles published between 2004 and 2011, and found that $24 \%$ were in OA. Jubb et al. (2015) published a report entitled Monitoring the transition to open access, commissioned to analyze the status of OA compliance in UK universities either by publishing in OA journals or by posting in institutional and subject repositories. The results revealed that $19 \%$ of articles, compared to those indexed in Scopus, were posted in repositories and available online, but this figure included articles that were already openly accessible on the publishers' sites immediately on publication; excluding these, the estimate would have been $9 \%$. In view of these results, it is clear that the data obtained depend on the sources of reference, how they are obtained and the discipline involved.

\section{Most universities request archiving of the author's peer-reviewed final draft or the publisher's version of record, in agreement with the version specified in the Spanish Science law, but there are also cases in which versions are not specified. This lack of specification leads to uncertainty that does not facilitate self-archiving}

In 2011 the European Commission announced a pilot initiative on OA to peer-reviewed research articles resulting from projects funded under the Seventh Framework Program (FP7) for a total of seven areas of knowledge (European Commission, 2011). In the Horizon 2020 program (H2020), the pilot has become a mandate that covers all areas of knowledge, with embargoes of 6 and 12 months, respectively, for science, technology, engineering and mathematics (STEM) and for social sciences and humanities (European Commission, 2016). To measure compliance with the OA policy of FP7 and H2020, OpenAIRE (a European project created to support the implementation of the OA policies of the European Commission and the European Research Council) harvests the metadata of the papers deposited in institutional repositories whose research is funded by the 
European Commission. To this end, the OpenAIRE guidelines use a project identifier field for standardized specification of the funding agency, in this case the European Commission (OpenAIRE, 2015). In fact, trials of this type have been carried out with the Fundação para a Ciência e a Tecnologia (FCT) and the Wellcome Trust. As of 6 October 2016, the statistics provided by OpenAIRE indicated that $64 \%$ of publications of projects under the $F P 7$ open access pilot were in $\mathrm{OA}$ (OpenAIRE, 2016a). According to data collected by OpenAl$R E$, the Fundação para a Ciência e a Tecnologia (FCT) reached a figure of $92.6 \%$, very similar to the $90.8 \%$ reached by the European Grid Initiative community (OpenAIRE, 2016b). Spanish institutional repositories have implemented these guidelines for European projects, but there is still no standard format for expressing information on national projects. The Spanish authorities are expected to publish a recommendation on project identification in the very near future, and it will then be possible to monitor national projects in a similar way to European projects.

In May 2016 the Schweizerischer Nationalfonds published a report on the monitoring of its mandate policy on the green and gold roads (Gutknecht et al., 2016). The report covered the period 2013-2015 and the sources of reference were initially the WoS and Scopus. The first analysis compared the publications in these citation databases that contained in the acknowledgments information on funding by the Swiss National Science Foundation (SNSF) with all OA publications, including those deposited in repositories, in OA journals and on personal websites. The level of coincidence was only $20 \%$. After a validation using the digital object identifier (DOI) and searching in other sources (DOAJ, PubMed, PubMed Central, OpenAIRE and the Astrophysics Data System), the figure reached $56 \%$, of which $27 \%$ corresponded to publications deposited in OA repositories; this value is close to that obtained by Borrego (2015) for OA publications in Spain.

\subsection{The OA context at national level in Spain}

The new Spanish Law 14/2011, on science, technology and innovation (hereafter the Spanish Science law), which contains an article on OA (article 37), was passed in 2011 (España, 2011; Fecyt, 2014). In accordance with this law, publications arising from projects funded by the general state budget should be deposited in an OA repository as soon as possible and no later than twelve months after the official date of publication. In fact, this requirement was already included in the latest calls of the Spanish National science, innovation and technology plan (Mineco, 2013; 2017). This requirement is in line with other policies such as those of H2020 (European Commission, 2016). However, according to Point 6 of Article 37 of the Law, the authors may be exempted from depositing if they have reached rights assignment agreements with third parties (in most cases with publishers). In addition, universities and research centers have established their own institutional policies for making the scholarly outputs of their staff available in OA, and for preserving them. Therefore, self-archiving of the scholarly publications of Spanish universities should be favored by both the Spanish Law and by any institutional mandates or recommendations that are in place.
Borrego (2015) conducted a study to estimate compliance with the Spanish Science law within the period 2011-2014 using the articles published in 2012 with government funding obtained. Taking a random sample of all the projects, he found that of all the articles of 2012 indexed in the WoS, at least $58.4 \%$ were available on the internet in OA journals, repositories or other websites. Of these articles, $23.8 \%$ were published in OA journals and $21.8 \%$ were archived in repositories; of the latter, most were in the subject repositories Arxiv or PubMed. In total, an average of $14.4 \%$ of the articles resulting from publicly funded research were available in institutional repositories, and the distribution between institutions was asymmetric. This figure is close to the $12.4 \%$ obtained by the Pasteur4OA Project (Open access policy alignment strategies for European Union research) for institutions with an institutional mandate (Swan et al., 2015).

Bearing in mind these precedents and the lack of information on monitoring of and compliance with OA policies in Spain, the aim of the present study was to analyze the degree of compliance with OA policies by Spanish universities from two points of view:

(a) Institutional compliance (for universities with institutional OA policies that require or encourage self-archiving of the scholarly publications of their staff), and (b) compliance with Article 37 of the Spanish Science law, which requires published papers resulting from projects funded by the Spanish government to be deposited as soon as possible and no later than 12 months after their publication. This analysis covered the period 2012-2014, in which the mandate of the Law was in force and at the time of the study the embargo period of 12 months laid down by the Law had expired. Moreover, taking into account both approaches to analyze if there are any synergy effects between the policies.

\section{Samples and methods}

To monitor compliance with $\mathrm{OA}$ institutional policies and compliance with the Spanish Law, we have to identify the total number of peer-reviewed articles subject to the policy, the total number of full-text OA articles in the repository, and the number of embargoed full-text items that will become OA at a later date, as suggested by Picarra (2015).

Compliance with institutional or governmental OA policies was analyzed in the period 2012-2014 to ensure that any embargoes had expired, on the assumption that in most journals the embargo period was less than 24 months (the Spanish Science law establishes a period of 12 months after publication). We used the Bielefeld Academic Search Engine (BASE) and its application programming interface (API) (Bielefeld University Library, 2016a; 2016b, respectively) to obtain the XML files with the records of the articles deposited in institutional repositories in this period. To obtain the published works subjected to the policy, we used the databases included in the WoS Core Collection (Clarivate Analytics, 2017).

\subsection{The Spanish universities studied}

We drew up a list of the 25 Spanish universities listed in the Melibea directory (Acceso Abierto, 2016) that have OA policies (mandate or recommendation). We also added 7 
Table 1. Spanish universities included in this study and their open access policies, if any

\begin{tabular}{|c|c|c|c|}
\hline University & Acronym & Open access policy & $\begin{array}{c}\text { Berlin declaration } \\
\text { signatory }\end{array}$ \\
\hline Univ. Carlos III de Madrid & UC3M & Mandate/Requirement & Yes \\
\hline Univ. Complutense de Madrid & UCM & Mandate/Requirement Mandate/Requirement & Yes \\
\hline Univ. de Burgos & $U B U$ & Mandate/Requirement & Yes \\
\hline Univ. de Huelva & $U H U$ & Mandate/Requirement & Yes \\
\hline Univ. de Las Palmas de Gran Canaria & ULPGC & Mandate/Requirement & Yes \\
\hline Univ. de León ${ }^{1}$ & UNILEON & Mandate/Requirement & Yes \\
\hline Univ. Nacional de Educación a Distancia & UNED & Mandate/Requirement & Yes \\
\hline Univ. Politécnica de Madrid & UPM & Mandate/Requirement & Yes \\
\hline Univ. Rey Juan Carlos & URJC & Mandate/Requirement & Yes \\
\hline Univ. Rovira i Virgili ${ }^{1}$ & URV & Mandate/Requirement & No \\
\hline Univ. Autònoma de Barcelona & $U A B$ & Mandate/Requirement & Yes \\
\hline Univ. de Barcelona & $U B$ & Mandate/Requirement & Yes \\
\hline Univ. Oberta de Catalunya & UOC & Mandate/Requirement & Yes \\
\hline Univ. Politècnica de Catalunya & $U P C$ & Mandate/Requirement & Yes \\
\hline Univ. CEU Cardenal Herrera & CEU & Recommend/Encourage & Yes \\
\hline Univ. de Alcalá & $U A H$ & Recommend/Encourage & Yes \\
\hline Univ. de Cantabria & UNICAN & Recommend/Encourage & Yes \\
\hline Univ. de Extremadura ${ }^{1}$ & UEX & Recommend/Encourage & No \\
\hline Univ. de Málaga' & $U M A$ & Recommend/Encourage & Yes \\
\hline Univ. Politécnica de Cartagena & UPCT & Recommend/Encourage & Yes \\
\hline Univ. Politécnica de Valencia & UPV & Recommend/Encourage & Yes \\
\hline Univ. de Girona & $U d G$ & Recommend/Encourage & Yes \\
\hline Univ. de Lleida & $U d L$ & Recommend/Encourage & Yes \\
\hline Univ. de Vic & UVIC & Recommend/Encourage & Yes \\
\hline Univ. Pompeu Fabra & UPF & Recommend/Encourage & Yes \\
\hline Univ. Autónoma de Madrid & $U A M$ & - & Yes \\
\hline Univ. de Alicante & $U A$ & - & Yes \\
\hline Univ. del País Vasco & $E H U$ & - & No \\
\hline Univ. Jaume I & 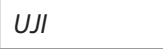 & - & Yes \\
\hline Univ. Pablo de Olavide & UPO & - & Yes \\
\hline Univ. Pública de Navarra & UPNA & - & Yes \\
\hline Univ. de València & UV & - & Yes \\
\hline
\end{tabular}

1. Excluded from this study (see Methods)

other universities that do not have an explicit policy but advocate in favor of OA and/or have signed the Berlin declaration on open access to knowledge in the sciences and humanities (Open access at the Max Planck Society, 2003). From these, we excluded the University of Extremadura and the University of Málaga because their institutional repositories contained only articles published in the universities' own journals. Also the University of León because it indexed the deposit date instead of the publication date in the field $d c$ :date or dc:year; and the Universitat Rovira i Virgili because its repository only contained doctoral theses at the time when the data were gathered. We analyzed a total of 28 institutions: twelve with an $\mathrm{OA}$ mandate, nine that encourage OA and seven without an institutional OA policy, all of which were subject to Article 37 of the Spanish Science law (Table 1).

Table 2 shows some features of the OA policies and the corresponding type according to the university OA policy classification proposed by Shieber and Suber (2015):

Type 1. The policy grants the institution certain non-exclusive rights to future research articles published by faculty sta$\mathrm{ff}$. This type of policy typically offers a waiver option or optout for authors. It also requires depositing in the repository.

Type 2 . The policy requires faculty to retain certain non-exclusive rights when they publish future research articles. Whether or not it offers a waiver option for authors, it requires depositing in the repository. 
Table 2. Some features of the institutional OA policies of studied universities

\begin{tabular}{|c|c|c|c|c|c|c|c|c|}
\hline $\begin{array}{l}\text { Institu- } \\
\text { tion }\end{array}$ & $\begin{array}{l}\text { Effective } \\
\text { from } \\
\text { YYYY-MM- } \\
\text { DD }\end{array}$ & OA policy & $\begin{array}{l}\text { Allow faculty to } \\
\text { opt-out of the } \\
\text { requirement? }\end{array}$ & $\begin{array}{l}\text { Versions of } \\
\text { papers }\end{array}$ & $\begin{array}{l}\text { When to } \\
\text { deposit }\end{array}$ & $\begin{array}{l}\text { Allowed } \\
\text { embargo }\end{array}$ & $\begin{array}{l}\text { Copyright reser- } \\
\text { vation }\end{array}$ & $\begin{array}{l}\text { Type } \\
\text { of } \\
\text { policy }\end{array}$ \\
\hline UNED & 2014-07-14 & $\begin{array}{l}\text { Green OA mandate } \\
\text { and recommended } \\
\text { gold OA }\end{array}$ & $\begin{array}{l}\text { No opt-out of de- } \\
\text { posit but opt-out } \\
\text { of immediate OA, } \\
\text { case by case }\end{array}$ & $\begin{array}{l}\text { Author's peer-re- } \\
\text { viewed final draft. } \\
\text { Publisher's version } \\
\text { of record }\end{array}$ & $\begin{array}{l}\text { At the time } \\
\text { of publica- } \\
\text { tion }\end{array}$ & 12 months & $\begin{array}{l}\text { The policy grants } \\
\text { the institution } \\
\text { certain non-ex- } \\
\text { clusive rights to } \\
\text { future research } \\
\text { articles published } \\
\text { by faculty }\end{array}$ & 1 \\
\hline UC3M & 2010-01-08 & Green OA mandate & $\begin{array}{l}\text { Both opt-outs of } \\
\text { deposit and of } \\
\text { immediate OA }\end{array}$ & $\begin{array}{l}\text { Author's peer-re- } \\
\text { viewed final draft. } \\
\text { Publisher's version } \\
\text { of record }\end{array}$ & Unspecified & $\begin{array}{l}\text { Estipulated by } \\
\text { the publisher }\end{array}$ & Unspecified & 4 \\
\hline CEU & 2014-03-06 & $\begin{array}{l}\text { Recommended } \\
\text { green and gold OA }\end{array}$ & Not applicable & Unspecified & $\begin{array}{l}\text { At the time } \\
\text { of publica- } \\
\text { tion }\end{array}$ & $\begin{array}{l}\text { Estipulated by } \\
\text { the publisher }\end{array}$ & $\begin{array}{l}\text { No copyright } \\
\text { reservation }\end{array}$ & 5 \\
\hline UCM & 2014-05-27 & Green OA mandate & $\begin{array}{l}\text { No opt-out of de- } \\
\text { posit but opt-out } \\
\text { of immediate OA }\end{array}$ & Unspecified & $\begin{array}{l}\text { As soon as } \\
\text { possible }\end{array}$ & $\begin{array}{l}\text { Estipulated by } \\
\text { the publisher }\end{array}$ & $\begin{array}{l}\text { University recom- } \\
\text { mends to avoid ex- } \\
\text { clusively copyright } \\
\text { transfers to allow } \\
\text { selfarchiving }\end{array}$ & 3 \\
\hline$U A H$ & 2013-03-21 & $\begin{array}{l}\text { Recommended } \\
\text { Green OA }\end{array}$ & Unspecified & Unspecified & Unspecified & $\begin{array}{l}\text { Estipulated by } \\
\text { the publisher }\end{array}$ & Unspecified & 5 \\
\hline UBU & 2014-03-31 & Green OA mandate & $\begin{array}{l}\text { Both opt-outs of } \\
\text { deposit and of } \\
\text { immediate OA }\end{array}$ & Unspecified & $\begin{array}{l}\text { As soon as } \\
\text { possible }\end{array}$ & $\begin{array}{l}\text { Estipulated by } \\
\text { the publisher }\end{array}$ & Unspecified & 4 \\
\hline UNICAN & 2012-07-24 & $\begin{array}{l}\text { Recommended } \\
\text { green and gold OA }\end{array}$ & Not applicable & $\begin{array}{l}\text { Author's peer-re- } \\
\text { viewed final draft. } \\
\text { Publisher's version } \\
\text { of record }\end{array}$ & $\begin{array}{l}\text { At the time } \\
\text { of accep- } \\
\text { tance or } \\
\text { publication }\end{array}$ & $\begin{array}{l}\text { Estipulated by } \\
\text { the publisher }\end{array}$ & Unspecified & 5 \\
\hline UHU & $2015-02-27$ & $\begin{array}{l}\text { Green OA mandate } \\
\text { and recommended } \\
\text { gold OA }\end{array}$ & $\begin{array}{l}\text { No opt-out of de- } \\
\text { posit but opt-out } \\
\text { of immediate OA }\end{array}$ & $\begin{array}{l}\text { Version allowed by } \\
\text { the publisher }\end{array}$ & $\begin{array}{l}\text { At the time } \\
\text { of accep- } \\
\text { tance }\end{array}$ & $\begin{array}{l}\text { Between } 6 \\
\text { and } \\
12 \text { months }\end{array}$ & $\begin{array}{l}\text { University recom- } \\
\text { mends to avoid ex- } \\
\text { clusively copyright } \\
\text { transfers to allow } \\
\text { selfarchiving }\end{array}$ & 3 \\
\hline ULPGC & 2015-10-08 & Green OA mandate & $\begin{array}{l}\text { No opt-out of de- } \\
\text { posit but opt-out } \\
\text { of immediate OA }\end{array}$ & Unspecified & $\begin{array}{l}\text { As soon as } \\
\text { possible }\end{array}$ & 12 months & $\begin{array}{l}\text { No copyright } \\
\text { reservation }\end{array}$ & 3 \\
\hline UPCT & 2011-04-13 & $\begin{array}{l}\text { Recommended } \\
\text { green and gold OA }\end{array}$ & Not applicable & $\begin{array}{l}\text { Author's peer-re- } \\
\text { viewed final draft. } \\
\text { Publisher's version } \\
\text { of record }\end{array}$ & Unspecified & Unspecified & Unspecified & 5 \\
\hline UPM & 2010-10-28 & $\begin{array}{l}\text { Green OA mandate } \\
\text { and recommended } \\
\text { gold OA }\end{array}$ & $\begin{array}{l}\text { No opt-out of de- } \\
\text { posit but opt-out } \\
\text { of immediate OA }\end{array}$ & Unspecified & Unspecified & $\begin{array}{l}\text { Estipulated by } \\
\text { the publisher }\end{array}$ & Unspecified & 3 \\
\hline$U A B$ & 2012-04-25 & $\begin{array}{l}\text { Green OA mandate } \\
\text { and recommended } \\
\text { gold OA }\end{array}$ & $\begin{array}{l}\text { No opt-out of de- } \\
\text { posit but opt-out } \\
\text { of immediate OA }\end{array}$ & $\begin{array}{l}\text { Author's peer-re- } \\
\text { viewed final draft. } \\
\text { Publisher's version } \\
\text { of record. Unrefer- } \\
\text { eed preprint }\end{array}$ & $\begin{array}{l}\text { At the time } \\
\text { of publica- } \\
\text { tion }\end{array}$ & 6 months & $\begin{array}{l}\text { No copyright } \\
\text { reservation }\end{array}$ & 3 \\
\hline$U B$ & 2012-01-01 & $\begin{array}{l}\text { Green OA mandate } \\
\text { and recommended } \\
\text { gold OA }\end{array}$ & $\begin{array}{l}\text { No opt-out of de- } \\
\text { posit but opt-out } \\
\text { of immediate OA }\end{array}$ & Unspecified & $\begin{array}{l}\text { At the time } \\
\text { of publica- } \\
\text { tion }\end{array}$ & 6 months & $\begin{array}{l}\text { No copyright } \\
\text { reservation }\end{array}$ & 3 \\
\hline UdG & 2012-01-09 & $\begin{array}{l}\text { Recommended } \\
\text { green and gold OA }\end{array}$ & Not applicable & $\begin{array}{l}\text { Author's peer-re- } \\
\text { viewed final draft. } \\
\text { Publisher's version } \\
\text { of record }\end{array}$ & $\begin{array}{l}\text { At the time } \\
\text { of publica- } \\
\text { tion }\end{array}$ & 6 months & Unspecified & 5 \\
\hline$U d L$ & $2012-05-30$ & $\begin{array}{l}\text { Recommended } \\
\text { green and gold OA }\end{array}$ & Not applicable & $\begin{array}{l}\text { Author's peer-re- } \\
\text { viewed final draft. } \\
\text { Publisher's version } \\
\text { of record }\end{array}$ & $\begin{array}{l}\text { At the time } \\
\text { of publica- } \\
\text { tion }\end{array}$ & 12 months & Unspecified & 5 \\
\hline UVIC & 2012-10-16 & $\begin{array}{l}\text { Recommended } \\
\text { green and gold OA }\end{array}$ & Not applicable & Unspecified & $\begin{array}{l}\text { At the time } \\
\text { of acep- } \\
\text { tance }\end{array}$ & 6 months & Unspecified & 5 \\
\hline
\end{tabular}




\begin{tabular}{|c|c|c|c|c|c|c|c|c|}
\hline UOC & 2010-10-06 & $\begin{array}{l}\text { Green OA mandate } \\
\text { and recommended } \\
\text { gold OA }\end{array}$ & $\begin{array}{l}\text { No opt-out of de- } \\
\text { posit but opt-out } \\
\text { of immediate OA }\end{array}$ & $\begin{array}{l}\text { Author's peer-re- } \\
\text { viewed final draft. } \\
\text { Publisher's version } \\
\text { of record }\end{array}$ & $\begin{array}{l}\text { At the time } \\
\text { of accep- } \\
\text { tance }\end{array}$ & 12 months & $\begin{array}{l}\text { The policy grants } \\
\text { the institution } \\
\text { certain non-ex- } \\
\text { clusive rights to } \\
\text { future research } \\
\text { articles published } \\
\text { by faculty }\end{array}$ & 1 \\
\hline$U P C$ & 2009-10-07 & $\begin{array}{l}\text { Green OA mandate } \\
\text { and recommended } \\
\text { gold OA }\end{array}$ & $\begin{array}{l}\text { No opt-out of de- } \\
\text { posit but opt-out } \\
\text { of immediate OA }\end{array}$ & $\begin{array}{l}\text { Author's peer-re- } \\
\text { viewed final draft. } \\
\text { Publisher's version } \\
\text { of record }\end{array}$ & $\begin{array}{l}\text { As soon as } \\
\text { possible }\end{array}$ & $\begin{array}{l}6 \text { months for } \\
\text { those funded } \\
\text { by national } \\
\text { projects }\end{array}$ & Unspecified & 3 \\
\hline UPV & 2011-07-21 & $\begin{array}{l}\text { Recommended } \\
\text { green and gold OA }\end{array}$ & Not applicable & $\begin{array}{l}\text { Author's peer-re- } \\
\text { viewed final draft, } \\
\text { Publisher's version } \\
\text { of record }\end{array}$ & $\begin{array}{l}\text { At the time } \\
\text { of publica- } \\
\text { tion }\end{array}$ & $\begin{array}{l}\text { Estipulated by } \\
\text { the publisher }\end{array}$ & $\begin{array}{l}\text { No copyright } \\
\text { reservation }\end{array}$ & 5 \\
\hline UPF & 2011-04-06 & $\begin{array}{l}\text { Recommended } \\
\text { green and gold OA }\end{array}$ & Not applicable & $\begin{array}{l}\text { Publisher's version } \\
\text { of record, pre-print }\end{array}$ & $\begin{array}{l}\text { At the time } \\
\text { of publica- } \\
\text { tion }\end{array}$ & 6 months & $\begin{array}{l}\text { No copyright } \\
\text { reservation }\end{array}$ & 5 \\
\hline
\end{tabular}

1. According to the Stuart Shieber and Peter Suber classification (Shieber; Suber, 2015).

Type 3. The policy seeks no rights at all, but requires depositing in the repository. If the institution already has permission to make a work OA, then it makes it OA from the moment of deposit. Otherwise, the deposit will be "dark" (non-OA) until the institution can obtain permission to make it OA. During the period of dark deposit, at least the metadata will be OA.

Type 4. The policy seeks no rights at all and does not require dark deposits. It requires repository depositing and OA, but only when the author's publisher permits them.

Type 5 . The policy does not require OA in any sense, but merely requests or encourages it.

Type 6. The policy does not require OA in any sense, but asks faculty to "opt in" to a policy under which they are expected to deposit their work in the repository and authorize it to be $O A$.

\section{The ratio of articles listed in the WoS that were published and deposited in institutional repositories (Deposit-INST) in the period 2012-2014 ranged from 1\% to $62 \%$}

\subsection{Obtaining the articles deposited in institutional repositories}

The metadata of the articles published in scholarly journals during the period 2012-2014 and deposited in repositories of the universities studied were harvested from BASE (Bielefeld University Library, 2016a). The XML files were obtained using the API of BASE. We executed an equation for each university with the following parameters:

(a) search function (func=PerformSearch);

(b) repository queried, named according to the BASE nomenclature (target=questioned<internal_name $>$ );

(c) fields consulted (query $=<$ queryterm $>\&(\ldots)$ ); (d) maximum number of bibliographic records returned by the equation (hits $=<$ number $>$ ); and

(e) fields returned by the query for each record (fields $=<-$ field1, field2... >).

The required fields in the search were:

dc:title (title of the document)

dc:creator (examples of a creator include a person, an organization, or a service)

$d c$ :contributor (an entity responsible for making contributions to the content of the resource)

dc:date (year of publication)

dc:identifier (example formal identification systems include the URI, URL and DOI)

dc:relation (the DC element relation can be used to indicate different kinds of relations between several metadata records)

dc:rights (open, embargoed or closed access to the document), and

dc:type (type of document).

If necessary, these fields might be repeated for each element (for example, the dc:identifier field would appear three times if it contains an URI, an URL and a DOI). The repositories collected met the OpenAIRE guidelines (OpenAI$R E, 2015)$, so in the description of the metadata they used the syntax of the guidelines. In the absence of a national standard for specifying projects financed by the Spanish government, some repositories provided this information in the $d c$ :relation field using their own criteria. In some cases by entering the project code, in others by entering the text of the acknowledgments of the articles, and in others using a syntax similar to that of European projects.

info:eu-repo/grantAgreement/Funder/FundingProgram/ ProjectID

As we were only interested in articles, we introduced in the search equation the restriction of articles in the document type, which according to the codes of the BASE API corresponds to 121 (doctype:121). 
For example, to retrieve the articles deposited in the repository of the University of Alicante (UA) that were published in the period 2012-2014, we designed the following equation:

https://api.base-search.net/cgi-bin/BaseHttpSearchlnterface. fcgi func $=$ PerformSearch \&target $=$ ftunivalicante $\&$ query=dcyear: $[2012+$ TO+2014]\&doctype:121\&fields=dctitle,dccreator,dccontributor,dcdate,dcidentifier,dcrelation,dcrights, dctype

In this case, target refers to the related institution name (ftunivalicante), dc:year to the period of publication (from 2012 to 2014), doc:type to the type of publication, and 121 code to articles.

The records retrieved for each university in XML format were exported and tabulated in a MS Excel spreadsheet. The records of each university were then manually checked.

\subsection{Obtaining the articles indexed in the WoS}

For each of the 28 universities, we implemented a search equation in the WoS to retrieve the articles published in the period 2012-2014. Each search equation was composed of two search lines. One line retrieved all the articles published by the university and the other retrieved only the articles financed by government funding bodies.

Both search sets queried (a) the Organization Data field (labeled $O G$ ) to select each university and (b) the Address field $(A D)$, where the variant names of each university were consulted. In addition, the search set that retrieved only the articles financed by public funding queried the fields Funding Agency (FO), Grant Number (FG) and Funding Text (FT) with the following terms referring to government funding: Spain,
Spanish, MINECO, MEC, MINCINN, Ministerio, Espana, CSIC, ISCIII, "Carlos III Health Institute", CICYT, "Consejo Superior de Investigaciones Cientificas", "Consolider Program", FICYT, FIS, "Fondo de Investigacion Sanitaria", "Fondo de Investigaciones Sanitarias", INIA, "Iniciativa Ingenio", "Instituto Carlos III", "Instituto de Salud Carlos III", MICINN, "Ministry of Economy and Competitiveness", "Ministry of Education", "Ministry of Education and Science", "Ministry of Science and Innovation" and "Ministry of Science and Technology".

The records retrieved for each university were then downloaded and tabulated in MS Excel.

The ratio of WoS articles deposited in repositories ranged from $2 \%$ to $76 \%$ for articles that acknowledged funding by Spanish government bodies (DepositGOV)

\subsection{Calculating the rate of $O A$ compliance by indivi- dual institutions}

We took as a reference of the published papers of an institution the articles indexed in the WoS databases in the period 2012-2014. For each university, we consulted each year and in the three years analyzed, we determined the total number of articles and, of these, the number of government-funded articles. We considered government-funded articles as a fraction of the whole output published by a university indexed in WoS. We identified the number of articles (funded and not funded) that were indexed in both WoS and

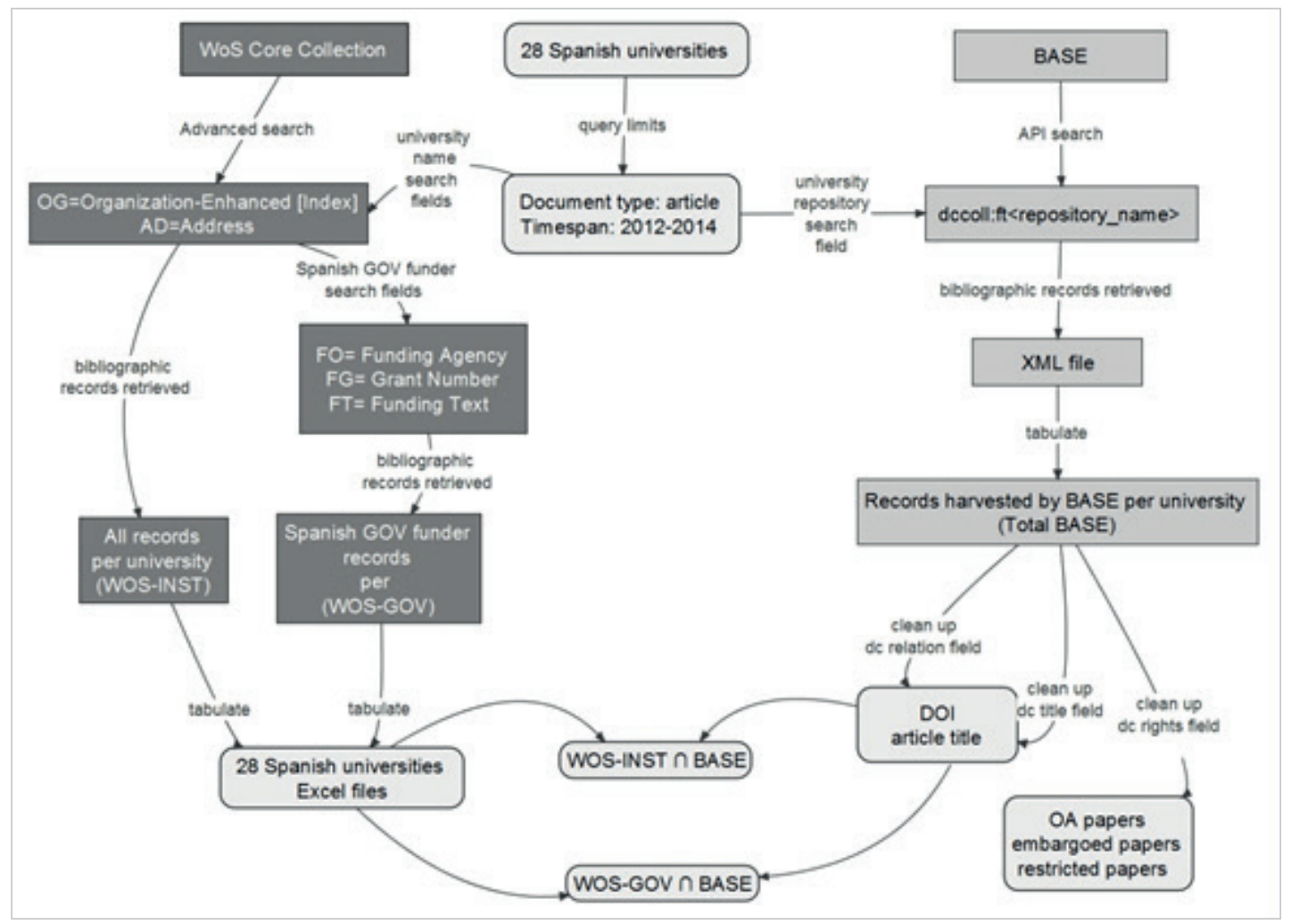

Figure 1. Flow chart of the search for articles indexed in the WoS and the data harvested from BASE to obtain the ratio of articles deposited in institutional repositories to the total published in 2012-2014 by 28 Spanish universities. 
BASE through an algorithm that consulted the DOls and the titles of the articles (Figure 1). If a DOI or title matched, the record was considered a positive match if the year of publication also coincided (note that the search already coincides with the type of document and one of the signatory institutions). The mismatched titles were sorted alphabetically and revised manually. Full stops were eliminated from the titles and the double (or longer) spaces were normalized to one.

Duplicates within an institution were eliminated, either because they were different versions of the same article or because there had been some duplication in the deposit by members of different departments. We did not take into account possible duplicates in repositories of different universities as a result of collaboration between researchers, because we were measuring compliance by institutions rather than overall compliance by country.

\section{The universities with the highest ratio of depositing showed the highest ratio of closed access (except UPM) but also the highest ratios of access to the rest of the articles}

The information in the dc:rights field was used to distinguish between articles that were OA, subject to embargo or closed according to the OpenAIRE guidelines. Previously, we checked that this field was correctly populated, but the time in which the repositories began to use it differed, so it appears in blank in some records.

The Institutional compliance index $(\mathrm{ICI})$ was calculated using the following equation:

$\mathrm{ICl}=$ (Total compliant articles archived in the period 2012-2014 (OA+embargoed))/(Total number of articles subject to the institutional policy in the period (2012-2014)indexed in WoS) $\times 100$

Where the numerator is the number of papers harvested from BASE and indexed in WoS, and the denominator is the total number of papers retrieved and indexed in WoS corresponding to a university within the period 2012-2014.

The Governmental compliance index ( $\mathrm{GCl}$ ) was calculated using the equation

$\mathrm{GCl}=$ (Total GOV-compliant articles archived in the period 2012-2014 (OA+embargoed))/(Total number of articles subject to the GOV-policy in the period (20122014)indexed in WoS) $\times 100$.

where the numerator is the number of papers harvested from BASE that acknowledge funding by a government entity and are indexed in the WoS, and the denominator is the total number of papers corresponding to the university within the period 2012-2014 that were retrieved and indexed in the WoS and acknowledged funding by a government body.
We also included embargoed papers in the equations because data were retrieved in 2016, two years after their publication, which was sufficient time to go beyond the permitted embargo of 12 months stated in the Spanish Science law.

\subsection{Calculating the potential self-archiving index}

The Potential self-archiving index (PAI) was defined as the proportion of articles subject to an institutional or governmental policy that can be deposited according to the archiving policies of the journals in which they are published and the color assigned by Sherpa/Romeo (a directory of publisher copyright policies and self-archiving): green, blue, yeIlow and white (Sherpa/Romeo, 2016a). We used the API of Sherpa/Romeo (Sherpa/Romeo, 2016b) to calculate the potential proportion of articles in green journals (which allow self-archiving in pre- and post-print version), in blue journals (which allow self-archiving in the post-print version), in yellow journals (which allow self-archiving in the pre-print version) and in white journals (which do not allow self-archiving). For each university, the calculation took into account all the articles indexed in the WoS that were subject to an institutional and governmental policy:

$\mathrm{PAI}=($ Articles indexed in WoS in the period $(2012-2014)$ classified by Romeo colours)/(Total number of articles subject to the policy in the period (2012-2014) indexed in WoS) $\times 100$

\section{Results and discussion}

Of the 28 universities studied, 12 have an OA mandate, 9 request or recommend $\mathrm{OA}$, and 7 have no formal $\mathrm{OA}$ institutional statement but are well known for their support to the OA movement. Table 2 shows some features of the OA institutional policies and the corresponding type according to the OA policy classification proposed by Shieber and Suber (2015). Policies of types 1 and 3 are the strongest, because they require archiving without exemption; if authors do not have permission, the deposit remains "dark" (non-OA) until the institution obtains permission to make it open. Type 1 corresponds to the model of Harvard University (Suber, 2015), adopted by the Spanish National University of Distance Education (UNED) and approved by its senate in July 2014. Type 3 requires archiving but not necessarily in open access, deposits might be embargoed or closed, but at least the metadata of the articles are openly available. The authors of this classification do not recommend policies of type 4 because they allow recalcitrant publishers to opt-out at will, and type 5 is a mere recommendation.

In summary, of the 28 universities studied, 12 have an institutional OA mandate, but only two do not allow to opt-out of archiving. Of the rest, nine do not require but request or encourage OA to scholarly outputs, and seven do not have a formal OA statement but are well known for their support to the OA movement.

Most universities request archiving of the author's peer-reviewed final draft or the publisher's version of record, in agreement with the version specified in the Spanish Science 
law, but there are also cases in which versions are not specified. This lack of specification leads to uncertainty that does not facilitate self-archiving. In addition, if it is not specified when the articles must be archived, it could be delayed indefinitely: the more loopholes there are, the weaker the policies are.

The date of application of the policies ranges from 2009 to 2015 , so the ones approved toward the end of the study period (2012-2014) will have had practically no effect on archiving. This is the case of the UNED (2014), the CEU Cardenal Herrera University (2014), the UCM (2014), the University of Burgos (UBU, 2014), the University of Huelva (UHU, 2015) and the University of Las Palmas de Gran Canaria (ULPGC, 2015).

\subsection{Papers published by universities in the period 2012-2014}

According to the data of the WoS, scholarly publications in the period 2012-2014 showed on average an annual growth of $5.5 \%$ and no changes were observed in the order of the universities by volume of articles published over the period (Figure 2A). In the WoS, the proportion of all articles that were funded by the Spanish government in the period 20122014 was above $50 \%$ for all the universities studied (Figure $2 \mathrm{~B})$, except for the UOC (25\%) and the UNED (39\%), which are distance learning universities. Rather than comparing universities by the total volume of articles published, which depends on their size, we show the average number of articles produced per tenured research staff member per year in the period 2012-2014 (Figure 2A), according to the data provided by the observatory Actividad Investigadora en la Universidad Española (Iuene, 2016). The Pompeu Fabra University (UPF), a small- to medium-sized university (approx. 8,000 students) had the highest ratio, with 3.63 articles per staff member, followed by the large universities $U A B$ and the $U B$ (> 40,000 students), with two articles per staff member.

\subsection{Ratio of articles deposited in institutional repo- sitories}

The ratio of articles listed in the WoS that were published and deposited in institutional repositories (Deposit-INST) in the

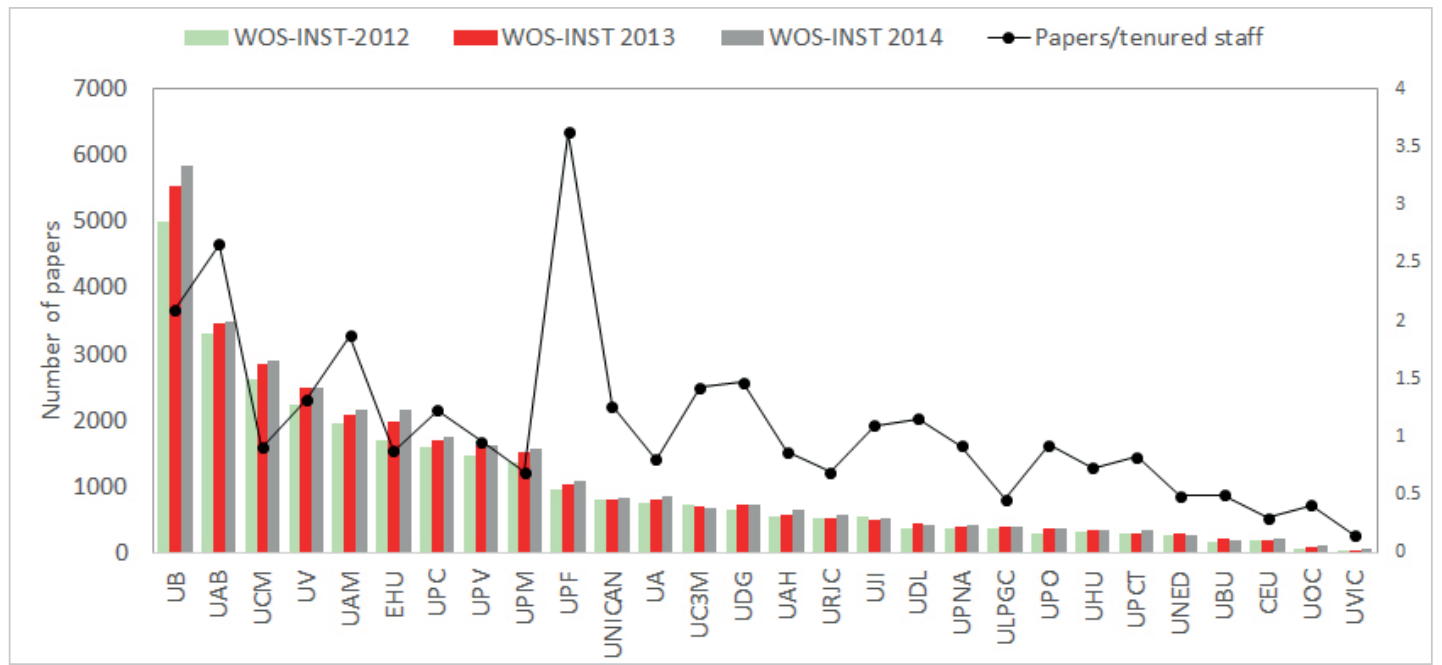

$2 A$

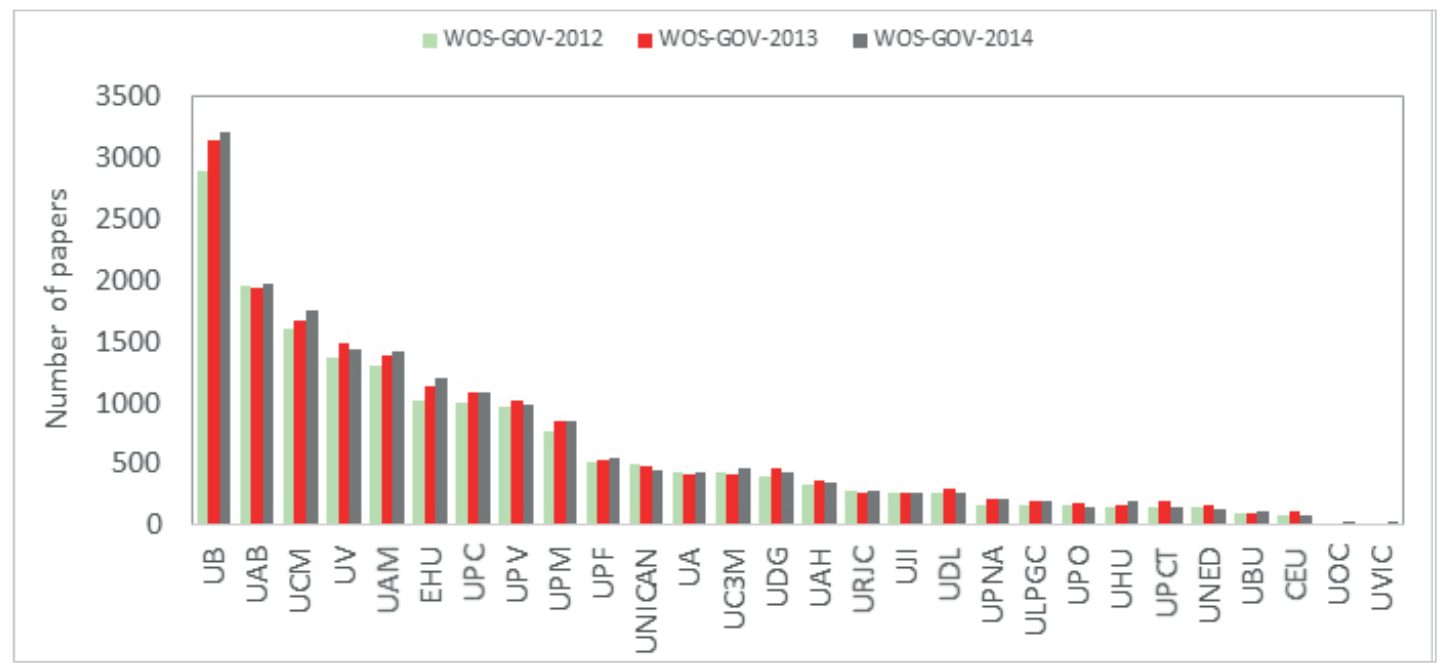

2B

Figure 2. (A) Number of articles published by the universities studied between 2012 and 2014. (B) Articles published by the universities studied between 2012 and 2014 that acknowledged funding by government bodies (Source: WoSCC, 2016). Continuous line shows the average number of articles per tenure staff in the same period (Source: luene, 2016). 
period 2012-2014 ranged from 1\% to $62 \%$ (Figure $3 \mathrm{~A}$ ). The universities with the highest ratios were small- to medium-sized universities (the University of Vic (UVIC) and the Jaume I University (UJI), with approx. 5000 and 15,000 students, respectively. In the case of the UVIC, only 136 articles were published and indexed in the WoS in the three years (see Table 4), so self-archiving or mediated deposit were facilitated by the low workload. At the Jaume I University (UJI), deposits are mainly mediated by the library, so the effect of voluntary deposits is minimized. In terms of the archiving ratio, the Universidad de Alicante, the Universitat Politècnica de Catalunya (UPC), the Universidad Politécnica de Valencia (UPV) and the Universidad Politécnica de Madrid (UPM) follow these universities. The UPC and the UPM have institutional OA mandates that state that authors cannot optout of depositing but can opt-out of immediate OA (see Table 2).

The ratio of WoS articles deposited in repositories ranged from $2 \%$ to $76 \%$ (Figure 3B) for articles that acknowledged funding by Spanish government bodies (Deposit-GOV).

Figure $3 \mathrm{C}$ shows the total number of papers indexed in the WoS in the period 2012-2014 (Total WoS) for each of the universities studied, and those that acknowledge funding by a governmental body (Total WoS-GOV). In almost all universities studied, the number of papers harvested from the repositories was very low compared with the number of published articles indexed in the WoS, with the exception of the UPC, the UA, the $U J I$, the University of Lleida (UdL), the UNED, the UHU and the UVIC. Of these, the UPV, the UA, the UJI and the UVIC had the highest ratios. The UNED had a very low ratio, but the number of papers deposited in its repository was higher than the number indexed in the WoS, so many of them were from other sources.

According to the data from the WoS Core Collection, the percentage of published articles deposited in repositories is slightly higher for government-funded articles (on average $55 \%$ of the total) than for the rest.

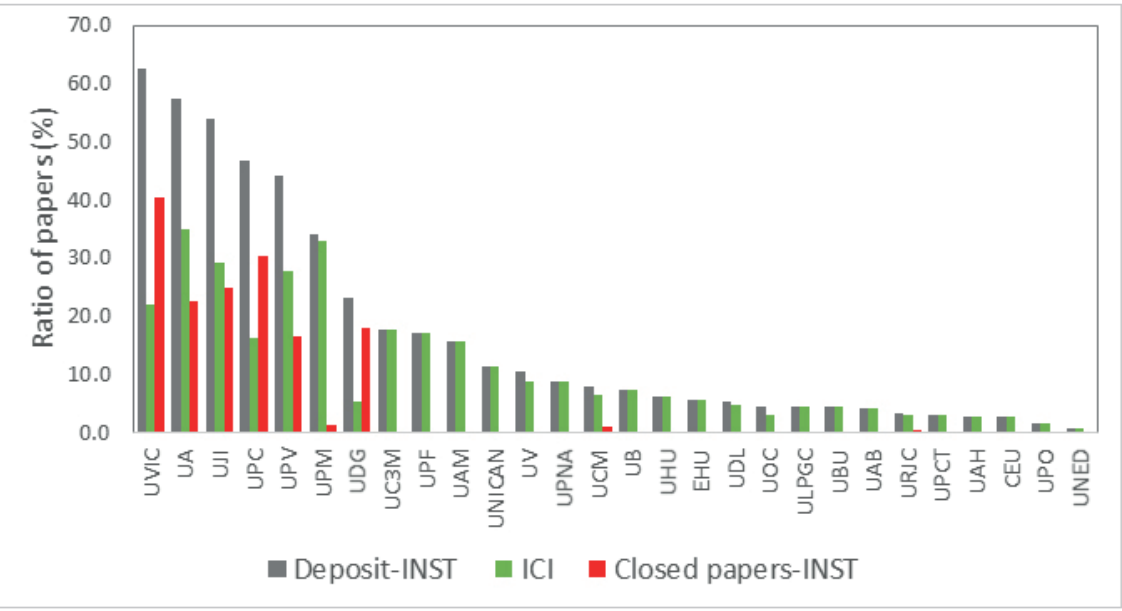

3A

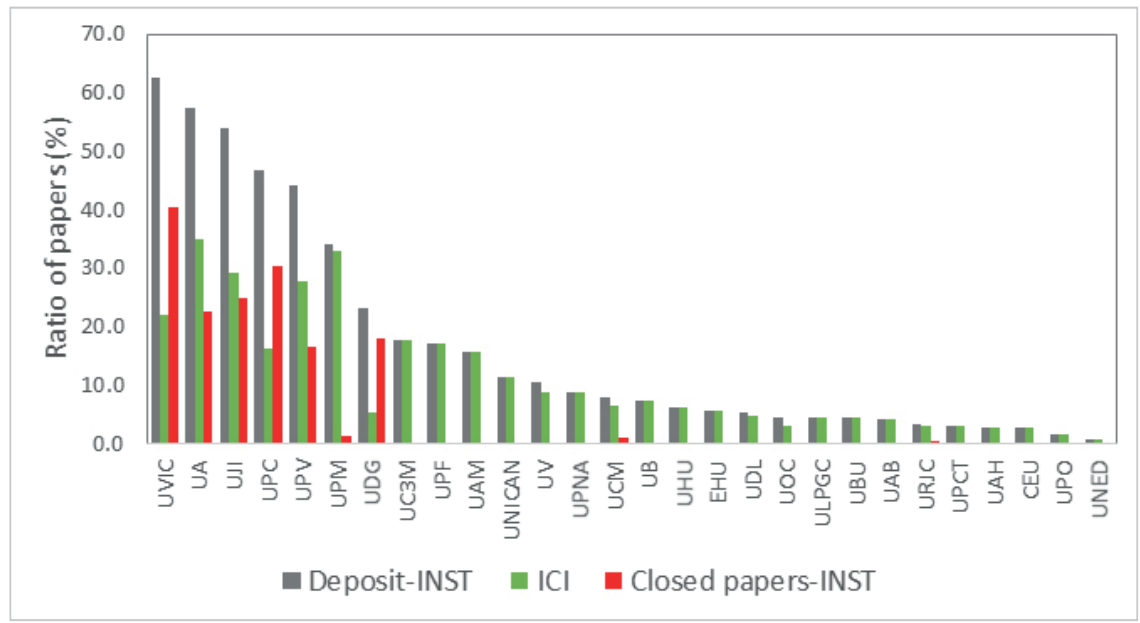

3B

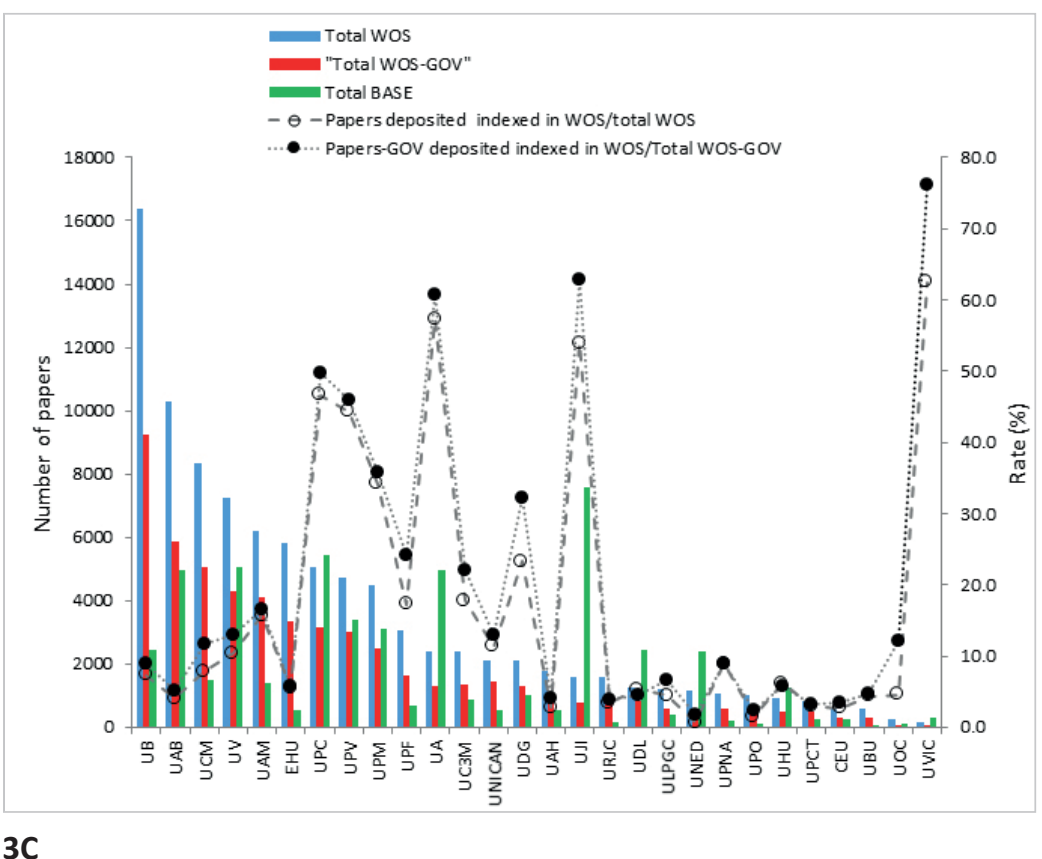

Figure 3. (A) Ratio of all articles indexed in the WoS that were deposited in the institutional repository (Deposit-INST) in relation to ICl and closed papers (Closed papers-INST). (B) Ratio of papers acknowledging funding by government bodies (Deposit-GOV) that were deposited (Deposit-GOV) in relation to $\mathrm{GCl}$ and closed papers (Closed papers-GOV). (C) Number of papers indexed in WoS (Total WOS), and of those total papers funded by government entities (Total WoS-GOV) compared to the ones archived in repositories (Total BASE) and percentage of matching with articles indexed in WoS. 
We classified the universities into three groups regarding the type of institutional policy: Group 1 represents universities with no institutional policy, Group 2 universities that encourage depositing and Group 3 universities that have a mandate. All three groups are subject to the Spanish Science law.

If we represent the depositing ratios and the $\mathrm{ICl}$ and $\mathrm{GCl}$ compliance indices separately for each group, we obtain the adjustments of Figures $4 \mathrm{~A}$ and $4 \mathrm{~B}$. In view of these results, there seem to be no differences between the three groups, so it is not possible to distinguish the effect of the institutional policies from the requirement established in Article 37 of the Spanish Science law. The data on $O A$ availability will be dealt with in the following section.

\subsection{Ratio of $O A$ articles archived in institutional repositories}

Not all deposited articles in institutional repositories were OA. Table 3 shows the results obtained from BASE for each university, identified by the metadata $d c$ :rights as openAccess, embargoedAcccess and closedAccess, terms from the info:eu-repo-Access-Terms vocabulary (Surfnet, 2013). According to this vocabulary, "embargoed access" means the resource is closed access until released for OA on a certain date, and "closed access" means that the item is not available in the public internet and is also known as "toll-gated access".

The dc:rights-empty column shows the number of records that could not be assigned to any of these categories. The UOC and the Universitat de València (UV) showed high figures of $32 \%$ and $47 \%$, respectively, which could have a considerable effect on the calculation of the articles that are available in OA in their repositories.

For each university we calculated the percentage of articles indexed in the WoS that were deposited in repositories and the percentage that were OA or closed access (Table 3). If we assume that the ones with an embargo will potentially be $O A$ after a certain time, the OA ratio for each university would be the sum of OA and embargoed articles.

In 23 of the universities studied, most of the articles archived in their repositories are available in OA (Table 3), with the exception of the following institutions, which had a significant percentage of closed papers: the UA (16\%), the UII (17\%), the UPV (29\%), the UPC (40\%), the UdG (47\%) and the UV (47\% of blank dc:rights metadata). Of these, the UPC has an OA mandate type 3 policy (Table 2 ) so the authors cannot opt-out of deposit but opt-out of immediate OA. The percentage of articles deposited, compared to the ones indexed in WoS, ranged from $0.7 \%$ to $62.5 \%$. The universities with the highest ratio of depositing (UA, UdG, UJI, UPC, UPV and UVIC) were also those with the highest percentage of closed access papers. Nevertheless, these universities still had the highest proportion of articles available in OA. 
Table 3. Number of articles harvested by BASE during the period 2012-2014, classified as open, embargoed and closed papers according to the element dc:rights

\begin{tabular}{|c|c|c|c|c|c|}
\hline \multirow{2}{*}{ University } & \multicolumn{5}{|c|}{ Number of harvested articles } \\
\hline & Total & Open access & Embargoed & Closed access & Dc:rights-empty* \\
\hline CEU & 238 & 238 & 0 & 0 & 0 \\
\hline$U A$ & 4,978 & 4,159 & 11 & 808 & 0 \\
\hline$U A B$ & 4,979 & 4,907 & 13 & 59 & 0 \\
\hline$\cup A H$ & 550 & 549 & 0 & 1 & 0 \\
\hline UAM & 1,392 & 1,381 & 11 & 0 & 0 \\
\hline$U B$ & 2,454 & 2,422 & 30 & 2 & 0 \\
\hline UBU & 59 & 59 & 0 & 0 & 0 \\
\hline UC3M & 853 & 819 & 33 & 1 & 0 \\
\hline UCM & 1,474 & 1,126 & 160 & 142 & $46(3 \%)$ \\
\hline UdG & 995 & 507 & 19 & 469 & 0 \\
\hline$U d L$ & 2,428 & 2,324 & 15 & 6 & 83 (3.4\%) \\
\hline UHU & 1,265 & 1,265 & 0 & 0 & 0 \\
\hline اנU & 7,588 & 6,287 & 2 & 1,298 & 1 (0.01\%) \\
\hline ULPGC & 399 & 399 & 0 & 0 & 0 \\
\hline UNED & 2,377 & 2,377 & 0 & 0 & 0 \\
\hline UNICAN & 525 & 525 & 0 & 0 & 0 \\
\hline UOC & 119 & 81 & 0 & 0 & $38(32 \%)$ \\
\hline UPC & 5,448 & 3,295 & 0 & 2,153 & 0 \\
\hline UPCT & 264 & 264 & 0 & 0 & 0 \\
\hline UPF & 704 & 701 & 3 & 0 & 0 \\
\hline UPM & 3,096 & 2,829 & 74 & 179 & $14(0.5 \%)$ \\
\hline UPNA & 198 & 188 & 10 & 0 & 0 \\
\hline UPO & 113 & 91 & 0 & 0 & $22(0.4 \%)$ \\
\hline UPV & 3,372 & 2,178 & 224 & 970 & 0 \\
\hline EHU & 562 & 561 & 1 & 0 & 0 \\
\hline URJC & 141 & 127 & 0 & 14 & 0 \\
\hline UV & 5,072 & 2,678 & 0 & 0 & $2394(47 \%)$ \\
\hline UVIC & 322 & 184 & 9 & 129 & 0 \\
\hline
\end{tabular}

${ }^{*} D c$ :rights empty means the element does not contain any information.

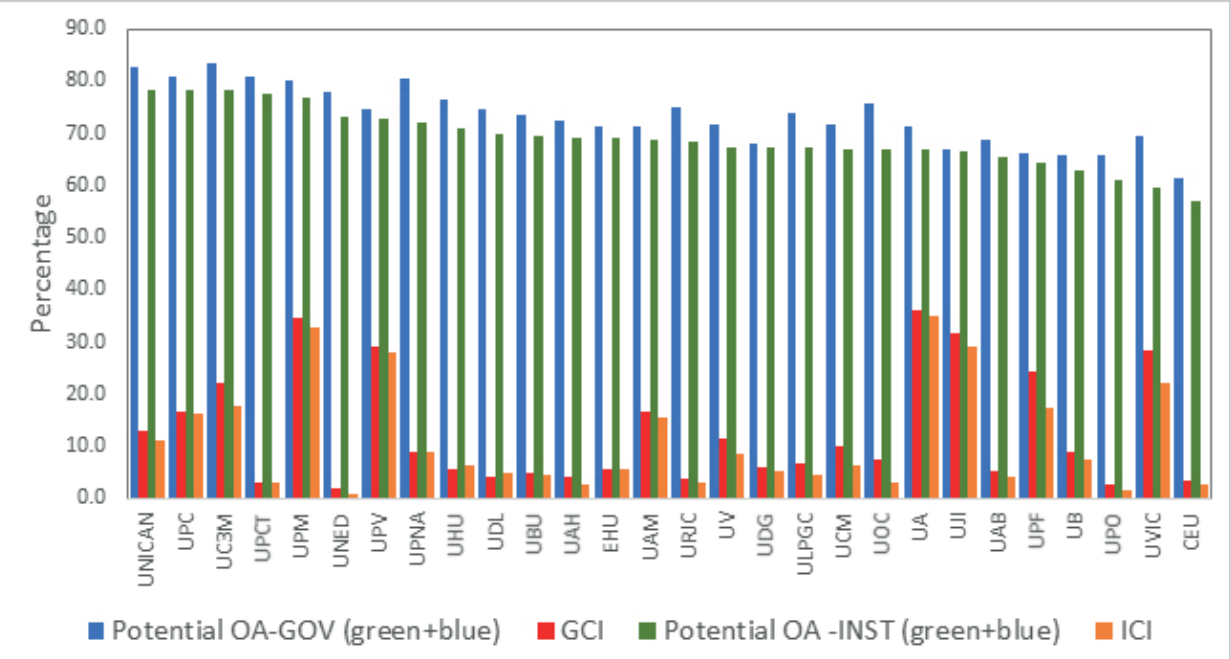

Figure 5. Comparison of real (measured as $\mathrm{ICl}$ and $\mathrm{GCl}$ ) and potential open access according to whether the articles had been published in green or blue journals based on the Sherpa/Romeo taxonomy. The graph includes all articles according to affiliation (INST) and those acknowledging funding by government bodies (GOV) 


\subsection{Calculating depositing and $O A$ of articles finan- ced through national projects}

Table 4 shows the number of articles indexed in the WoS that acknowledge funding from government bodies and the number of these that are deposited. The behavior is similar to that of the previous section. The universities with the highest ratio of depositing (UA, UdG, UJI, UPC, UPM, UPV and UVIC) showed the highest ratio of closed access (except the UPM with $1.3 \%$ ), but also the highest ratios of access to the rest of the articles. In the rest of the universities, closed access was zero or very low. The range of values ( $2 \%$ to $36 \%$ ) was slightly higher than that calculated taking into account the articles of the whole institution, regardless of funding.

The UPC and the UPM were included in a study reported by the Pasteur4OA project to analyze OA policies in Europe in the period 2011-2013 (Swan et al., 2015). In comparison with our findings, the rate of OA papers is slightly higher: $32.8 \%$ and $16.2 \%$ for the UPM and the UPC, respectively, compared with $26.2 \%$ and $13.9 \%$ for the UPM and the UPC, respectively. This difference could be due to the period used to calculate that percentage, which in our case was 20122014 , one year ahead.

The results show that the potential OA of published papers ranged between $60 \%$ and $80 \%$, well above the average

\subsection{Potential OA by universities according to journal archiving policies}

Each of the articles gathered from the WoS was given a Sherpa/Romeo color according to the policy of the journal in which it had been published. The colors (green, blue, yellow and white) indicate whether the journal allows self-archiving and at what stage of the publication process. From all the records of the WoS for the period 2012-2014 for each university, we obtained the data shown in Table 6.

Green and blue indicate that the publisher's version or the

Table 4. Total articles published and indexed in WoS by the corresponding university from 2012 to 2014, number of total deposits and closed papers, and $\mathrm{ICI}$ (Institutional compliance index)

\begin{tabular}{|c|c|c|c|c|c|c|c|c|}
\hline \multirow{2}{*}{ University } & \multirow{2}{*}{ WoS total } & \multicolumn{2}{|c|}{ Total deposited } & \multicolumn{2}{|c|}{ Closed } & \multirow{2}{*}{ OA } & \multirow{2}{*}{ Embargoed } & \multirow{2}{*}{$\begin{array}{l}\text { ICI } \\
\text { (\%) }\end{array}$} \\
\hline & & $\mathbf{n}$ & $\%$ & $\mathbf{n}$ & $\%$ & & & \\
\hline CEU & 575 & 15 & 2.6 & 0 & & 15 & 0 & 2.6 \\
\hline$U A$ & 2,416 & 1,384 & 57.3 & 542 & 22.4 & 836 & 6 & 34.9 \\
\hline$U A B$ & 10,276 & 416 & 4.0 & 1 & 0.0 & 412 & 3 & 4.0 \\
\hline$U A H$ & 1,759 & 48 & 2.7 & 0 & & 48 & 0 & 2.7 \\
\hline UAM & 6,197 & 970 & 15.7 & 0 & 0.0 & 960 & 10 & 15.7 \\
\hline$U B$ & 16,363 & 1,198 & 7.3 & 1 & 0.0 & 1185 & 12 & 7.3 \\
\hline$U B U$ & 571 & 25 & 4.4 & 0 & & 25 & 0 & 4.4 \\
\hline UC3M & 2,393 & 425 & 17.8 & 0 & & 400 & 25 & 17.8 \\
\hline UCM & 8,363 & 654 & 7.8 & 82 & 1.0 & 442 & 97 & 6.4 \\
\hline UdG & 2,110 & 490 & 23.2 & 377 & 17.9 & 100 & 13 & 5.4 \\
\hline$U d L$ & 1,238 & 66 & 5.3 & 3 & 0.2 & 53 & 7 & 4.8 \\
\hline UHU & 925 & 57 & 6.2 & 0 & & 57 & 0 & 6.2 \\
\hline ונU & 1,596 & 861 & 53.9 & 396 & 24.8 & 464 & 0 & 29.1 \\
\hline ULPGC & 1,191 & 53 & 4.5 & 0 & & 53 & 0 & 4.5 \\
\hline UNED & 1,140 & 8 & 0.7 & 0 & & 8 & 0 & 0.7 \\
\hline UNICAN & 2,111 & 238 & 11.3 & 0 & & 238 & 0 & 11.3 \\
\hline UOC & 264 & 12 & 4.5 & 0 & & 8 & 0 & 3.0 \\
\hline UPC & 5,040 & 2,349 & 46.6 & 1532 & 30.4 & 817 & 0 & 16.2 \\
\hline UPCT & 835 & 25 & 3.0 & 0 & & 25 & 0 & 3.0 \\
\hline UPF & 3,076 & 529 & 17.2 & 0 & & 527 & 2 & 17.2 \\
\hline UPM & 4,464 & 1,527 & 34.2 & 58 & 1.3 & 1407 & 59 & 32.8 \\
\hline UPNA & 1,059 & 94 & 8.9 & 0 & & 84 & 10 & 8.9 \\
\hline UPO & 1,022 & 15 & 1.5 & 0 & & 15 & 0 & 1.5 \\
\hline UPV & 4,716 & 2,088 & 44.3 & 774 & 16.4 & 1121 & 193 & 27.9 \\
\hline EHU & 5,828 & 323 & 5.5 & 0 & & 323 & 0 & 5.5 \\
\hline URJC & 1,566 & 54 & 3.4 & 6 & 0.4 & 48 & 0 & 3.1 \\
\hline UV & 7,227 & 752 & 10.4 & 0 & & 630 & 0 & 8.7 \\
\hline UVIC & 136 & 85 & 62.5 & 55 & 40.4 & 24 & 6 & 22.1 \\
\hline
\end{tabular}


Table 5. Total articles published and indexed in WoS with mention of funding by a government body (WoS-GOV) during the period 2012-2014, number of total deposits and closed papers and $\mathrm{GCl}$ (Government compliance index).

\begin{tabular}{|c|c|c|c|c|c|c|c|c|}
\hline \multirow{2}{*}{ University } & \multirow{2}{*}{$\begin{array}{l}\text { Total papers } \\
\text { WoS-GOV }\end{array}$} & \multicolumn{2}{|c|}{ Total deposits } & \multicolumn{2}{|c|}{ Closed papers } & \multirow{2}{*}{ OA papers } & \multirow{2}{*}{$\begin{array}{c}\text { Embargoed } \\
\text { papers }\end{array}$} & \multirow{2}{*}{ GCI $(\%$} \\
\hline & & $\mathrm{n}$ & $\%$ & $n$ & $\%$ & & & \\
\hline CEU & 283 & 10 & 3.5 & 0 & 0.0 & 10 & 0 & 3.5 \\
\hline$U A$ & 1,297 & 788 & 60.8 & 318 & 24.5 & 467 & 3 & 36.2 \\
\hline$U A B$ & 5,879 & 298 & 5.1 & 1 & 0.0 & 295 & 2 & 5.1 \\
\hline$U A H$ & 1,049 & 42 & 4.0 & 0 & & 42 & 0 & 4.0 \\
\hline UAM & 4,104 & 678 & 16.5 & 0 & & 672 & 6 & 16.5 \\
\hline$U B$ & 9,246 & 821 & 8.9 & 1 & 0.0 & 809 & 11 & 8.9 \\
\hline$U B U$ & 314 & 15 & 4.8 & 0 & & 15 & 0 & 4.8 \\
\hline UC3M & 1,330 & 293 & 22.0 & 0 & & 282 & 11 & 22.0 \\
\hline UCM & 5,036 & 587 & 11.7 & 61 & 1.2 & 411 & 90 & 9.9 \\
\hline UdG & 1,297 & 419 & 32.3 & 343 & 26.4 & 67 & 9 & 5.9 \\
\hline$U d L$ & 824 & 38 & 4.6 & 3 & 0.4 & 30 & 3 & 4.0 \\
\hline UHU & 510 & 29 & 5.7 & 0 & & 29 & 0 & 5.7 \\
\hline II & 799 & 503 & 63.0 & 248 & 31.0 & 254 & 0 & 31.8 \\
\hline ULPGC & 568 & 38 & 6.7 & 0 & & 38 & 0 & 6.7 \\
\hline UNED & 454 & 8 & 1.8 & 0 & & 8 & 0 & 1.8 \\
\hline UNICAN & 1,446 & 188 & 13.0 & 0 & & 188 & 0 & 13.0 \\
\hline UOC & 66 & 8 & 12.1 & 0 & & 5 & 0 & 7.6 \\
\hline UPC & 3,170 & 1,575 & 49.7 & 1,046 & 33.0 & 529 & 0 & 16.7 \\
\hline UPCT & 501 & 16 & 3.2 & 0 & 0.0 & 16 & 0 & 3.2 \\
\hline UPF & 1,616 & 391 & 24.2 & 0 & 0.0 & 389 & 2 & 24.2 \\
\hline UPM & 2,473 & 887 & 35.9 & 28 & 1.1 & 830 & 27 & 34.7 \\
\hline UPNA & 597 & 54 & 9.0 & 0 & & 51 & 3 & 9.0 \\
\hline UPO & 486 & 12 & 2.5 & 0 & & 12 & 0 & 2.5 \\
\hline UPV & 2,989 & 1,376 & 46.0 & 509 & 17.0 & 743 & 124 & 29.0 \\
\hline$E H U$ & 3,357 & 191 & 5.7 & 0 & & 191 & 0 & 5.7 \\
\hline URJC & 834 & 32 & 3.8 & 1 & 0.1 & 31 & 0 & 3.7 \\
\hline UV & 4,298 & 558 & 13.0 & 0 & & 494 & 0 & 11.5 \\
\hline UVIC & 46 & 35 & 76.1 & 22 & 47.8 & 11 & 2 & 28.3 \\
\hline
\end{tabular}

accepted reviewed post-print can be deposited. Because this is the condition of Article 37 of the Spanish Science law, we took the sum of the two as potential OA, i.e. what the $O A$ ratio would have been if the authors had made full use of the possibility of self-archiving. The results show that the potential OA of published papers ranged between $60 \%$ and $80 \%$, well above the average.

\subsection{Potential $O A$ of articles with government funding according to journal archiving policies}

As in the previous section, this calculation was made with the articles that acknowledged funding from one of the bodies mentioned in the methodology. The results are shown in Table 7.

Both for all the articles (INST) and for those acknowledging funding from government bodies (GOV), the real percentages were below the potential ones indicated by the Sherpa/ Romeo color codes (Figure 6).

Comparing the real data with the potential one for articles published in green and blue journals, we found differences of $30 \%$ to $70 \%$, showing that depositing is still far lower than it could be. If repositories took advantage of this, the archiving rate could rise enormously, but in order to reach those figures, repository managers and/or librarians should track the articles published by their staff, and authors should take care to keep at least the version accepted for publication.

\subsection{Limitations of the study}

The limitations of this study are related to the sources used, which may have influenced the results obtained:

- The WoS limits the sources of reference to journals indexed in this database, so a future study should use other databases, such as Scopus (which includes Medline). However, the WoS includes the most important scientific publications in each subject area (Ruiz-Pérez; Delgado-López-Cózar; Jiménez-Contreras, 2006; Ruiz-Pérez; Delgado-López-Cózar, 2013), while Scopus over-represents peripheral literature in the scientific communication system (López-Illescas; De-Moya-Anegón; Moed, 2008; Bartol et al., 2014). 
Tabla 6. Potential self-archiving index (PAI) of total papers indexed in WoS corresponding to Spanish universities (with or without funding statement) classified by colors according to the journal in which they were published and the Sherpa/Romeo journal taxonomy (green, blue, yellow and white, see definitions in section 2.5 in methods).

\begin{tabular}{|c|c|c|c|c|c|c|c|c|c|}
\hline \multirow{2}{*}{ University } & \multicolumn{4}{|c|}{ Published papers in 2012-2014 } & \multicolumn{2}{|c|}{ White } & \multicolumn{3}{|c|}{ PAI (\%) } \\
\hline & Total & Green & Blue & Yellow & $\mathbf{n}$ & $\%$ & Green & Blue & Yellow \\
\hline CEU & 575 & 284 & 44 & 118 & 88 & 15.3 & 49.4 & 7.7 & 20.5 \\
\hline$U A$ & 2416 & 1443 & 176 & 341 & 265 & 11.0 & 59.7 & 7.3 & 14.1 \\
\hline$U A B$ & 10,276 & 6,193 & 529 & 1,971 & 997 & 9.7 & 60.3 & 5.1 & 19.2 \\
\hline$U A H$ & 1,759 & 1,129 & 89 & 256 & 174 & 9.9 & 64.2 & 5.1 & 14.6 \\
\hline UAM & 6,197 & 3,947 & 325 & 880 & 627 & 10.1 & 63.7 & 5.2 & 14.2 \\
\hline$U B$ & 16,363 & 9,400 & 915 & 3326 & 1,828 & 11.2 & 57.4 & 5.6 & 20.3 \\
\hline$U B U$ & 571 & 361 & 36 & 59 & 75 & 13.1 & 63.2 & 6.3 & 10.3 \\
\hline UC3M & 2,393 & 1,770 & 100 & 322 & 50 & 2.1 & 74.0 & 4.2 & 13.5 \\
\hline UCM & 8,363 & 5,030 & 581 & 1,218 & 888 & 10.6 & 60.1 & 6.9 & 14.6 \\
\hline UdG & 2,110 & 1,296 & 127 & 327 & 269 & 12.7 & 61.4 & 6.0 & 15.5 \\
\hline$U d L$ & 1,238 & 804 & 62 & 189 & 83 & 6.7 & 64.9 & 5.0 & 15.3 \\
\hline UHU & 925 & 580 & 78 & 96 & 67 & 7.2 & 62.7 & 8.4 & 10.4 \\
\hline الU & 1,596 & 975 & 87 & 232 & 204 & 12.8 & 61.1 & 5.5 & 14.5 \\
\hline ULPGC & 1,191 & 735 & 68 & 199 & 83 & 7.0 & 61.7 & 5.7 & 16.7 \\
\hline UNED & 1,140 & 705 & 127 & 133 & 65 & 5.7 & 61.8 & 11.1 & 11.7 \\
\hline UNICAN & 2,111 & 1,564 & 92 & 216 & 120 & 5.7 & 74.1 & 4.4 & 10.2 \\
\hline UOC & 264 & 134 & 43 & 58 & 5 & 1.9 & 50.8 & 16.3 & 22.0 \\
\hline UPC & 5,040 & 3,767 & 183 & 602 & 254 & 5.0 & 74.7 & 3.6 & 11.9 \\
\hline UPCT & 835 & 621 & 28 & 101 & 39 & 4.7 & 74.4 & 3.4 & 12.1 \\
\hline UPF & 3,076 & 1,734 & 247 & 749 & 206 & 6.7 & 56.4 & 8.0 & 24.3 \\
\hline UPM & 4,464 & 3,150 & 272 & 452 & 240 & 5.4 & 70.6 & 6.1 & 10.1 \\
\hline UPNA & 1,059 & 707 & 58 & 182 & 49 & 4.6 & 66.8 & 5.5 & 17.2 \\
\hline UPO & 1,022 & 537 & 87 & 188 & 100 & 9.8 & 52.5 & 8.5 & 18.4 \\
\hline UPV & 4,716 & 3,226 & 212 & 563 & 411 & 8.7 & 68.4 & 4.5 & 11.9 \\
\hline EHU & 5,828 & 3,792 & 232 & 730 & 723 & 12.4 & 65.1 & 4.0 & 12.5 \\
\hline URJC & 1,566 & 983 & 88 & 298 & 95 & 6.1 & 62.8 & 5.6 & 19.0 \\
\hline UV & 7,227 & 4,471 & 405 & 1,030 & 810 & 11.2 & 61.9 & 5.6 & 14.3 \\
\hline UVIC & 136 & 62 & 19 & 27 & 12 & 8.8 & 45.6 & 14.0 & 19.9 \\
\hline
\end{tabular}

- The effective date of the OA institutional policies is not the same for the institutions studied, so the effects of those policies are not completely comparable.

- We only considered institutional repositories to monitor OA compliance, but the Spanish Science law also permits self-archiving in subject repositories.

- The quality of the metadata on the source of funding was not optimal because not all records contain the information needed to describe the funding source, or it is not normalized.

- The Sherpa/Romeo database aims to be regularly updated, but editorial policies change even faster, so data accuracy is not $100 \%$ guaranteed.

\section{Conclusions}

Compliance with governmental and institutional OA policies varies greatly from one university to another, with an average of $11 \%$, a maximum of $33 \%$ and a minimum of $0.7 \%$. Compliance with Article 37 of the Spanish Science law is slightly higher, at $13 \%, 2 \%$ and $36 \%$, respectively.
Comparing the depositing rate with the OA rate, universities with the highest percentage of $O A$ also had the highest percentage of closed access, sometimes as much as $50 \%$. This effect is due to the depositing of the publisher's version, which may prevent $O A$, since authors do not have permission to self-archive except when they publish in $\mathrm{OA}$ journals. According to the potential OA results, it seems that the post-print version is not being used widely for depositing, or there is a preference for the publisher's version (version of record).

Universities with a low or null closed papers ratio have a low rate of coincidence with the papers indexed in the WoS, and the number of papers deposited is well below the number published. However, most publications available in their repositories are $O A$; this might be due to an internal institutional policy of depositing only what can be openly available, as the Carlos III University of Madrid (UC3M) does, for example. In this case, repositories do not provide the option to include metadata of publications that could be deposited but remain closed until they can be released. 
Table 7. Potential self-archiving index (PAI) of articles subjected to the governmental policy (PAI-GOV) that can be deposited according to the archiving policies of their journals and the color assigned by Sherpa/Romeo (green, blue, yellow and white, see definitions in section 2.5 in methods).

\begin{tabular}{|c|c|c|c|c|c|c|c|c|c|}
\hline \multirow{3}{*}{ University } & \multicolumn{6}{|c|}{$\begin{array}{l}\text { Published papers in } 2012-2014 \\
\text { funded by government projects }\end{array}$} & \multicolumn{3}{|c|}{ PAI-GOV (\%) } \\
\hline & \multirow{2}{*}{ Total } & \multirow{2}{*}{ Green } & \multirow{2}{*}{ Blue } & \multirow{2}{*}{ Yellow } & \multicolumn{2}{|c|}{ White } & \multirow{2}{*}{ Green } & \multirow{2}{*}{ Blue } & \multirow{2}{*}{ Yellow } \\
\hline & & & & & $\mathbf{n}$ & $\%$ & & & \\
\hline CEU & 283 & 161 & 13 & 57 & 49 & 17.3 & 56.9 & 4.6 & 20.1 \\
\hline$U A$ & 1,297 & 865 & 61 & 158 & 152 & 11.7 & 66.7 & 4.7 & 12.2 \\
\hline$U A B$ & 5,879 & 3,822 & 227 & 1,001 & 651 & 11.1 & 65.0 & 3.9 & 17.0 \\
\hline$U A H$ & 1,049 & 735 & 24 & 141 & 124 & 11.8 & 70.1 & 2.3 & 13.4 \\
\hline UAM & 4,104 & 2,781 & 149 & 511 & 474 & 11.5 & 67.8 & 3.6 & 12.5 \\
\hline$U B$ & 9,246 & 5,636 & 452 & 1,754 & 1,167 & 12.6 & 61.0 & 4.9 & 19.0 \\
\hline$U B U$ & 314 & 227 & 4 & 23 & 50 & 15.9 & 72.3 & 1.3 & 7.3 \\
\hline UC3M & 1,330 & 1,090 & 22 & 128 & 29 & 2.2 & 82.0 & 1.7 & 9.6 \\
\hline UCM & 5,036 & 3,446 & 166 & 667 & 600 & 11.9 & 68.4 & 3.3 & 13.2 \\
\hline UdG & 1,297 & 815 & 68 & 180 & 193 & 14.9 & 62.8 & 5.2 & 13.9 \\
\hline$U d L$ & 824 & 592 & 24 & 116 & 72 & 8.7 & 71.8 & 2.9 & 14.1 \\
\hline UHU & 510 & 381 & 9 & 49 & 50 & 9.8 & 74.7 & 1.8 & 9.6 \\
\hline ונU & 799 & 530 & 6 & 107 & 138 & 17.3 & 66.3 & 0.8 & 13.4 \\
\hline ULPGC & 568 & 398 & 22 & 70 & 49 & 8.6 & 70.1 & 3.9 & 12.3 \\
\hline UNED & 454 & 347 & 6 & 53 & 38 & 8.4 & 76.4 & 1.3 & 11.7 \\
\hline UNICAN & 1,446 & 1,153 & 45 & 127 & 81 & 5.6 & 79.7 & 3.1 & 8.8 \\
\hline UOC & 66 & 48 & 2 & 13 & 1 & 1.5 & 72.7 & 3.0 & 19.7 \\
\hline UPC & 3,170 & 2,495 & 73 & 352 & 165 & 5.2 & 78.7 & 2.3 & 11.1 \\
\hline UPCT & 501 & 396 & 9 & 47 & 30 & 6.0 & 79.0 & 1.8 & 9.4 \\
\hline UPF & 1,616 & 945 & 126 & 413 & 111 & 6.9 & 58.5 & 7.8 & 25.6 \\
\hline UPM & 2,473 & 1,902 & 81 & 254 & 134 & 5.4 & 76.9 & 3.3 & 10.3 \\
\hline UPNA & 597 & 454 & 27 & 72 & 27 & 4.5 & 76.0 & 4.5 & 12.1 \\
\hline UPO & 486 & 296 & 23 & 87 & 59 & 12.1 & 60.9 & 4.7 & 17.9 \\
\hline UPV & 2,989 & 2,148 & 82 & 315 & 320 & 10.7 & 71.9 & 2.7 & 10.5 \\
\hline EHU & 3,357 & 2,325 & 66 & 365 & 501 & 14.9 & 69.3 & 2.0 & 10.9 \\
\hline URJC & 834 & 606 & 20 & 144 & 45 & 5.4 & 72.7 & 2.4 & 17.3 \\
\hline UV & 4,298 & 2,950 & 132 & 515 & 555 & 12.9 & 68.6 & 3.1 & 12.0 \\
\hline UVIC & 46 & 29 & 3 & 10 & 3 & 6.5 & 63.0 & 6.5 & 21.7 \\
\hline
\end{tabular}

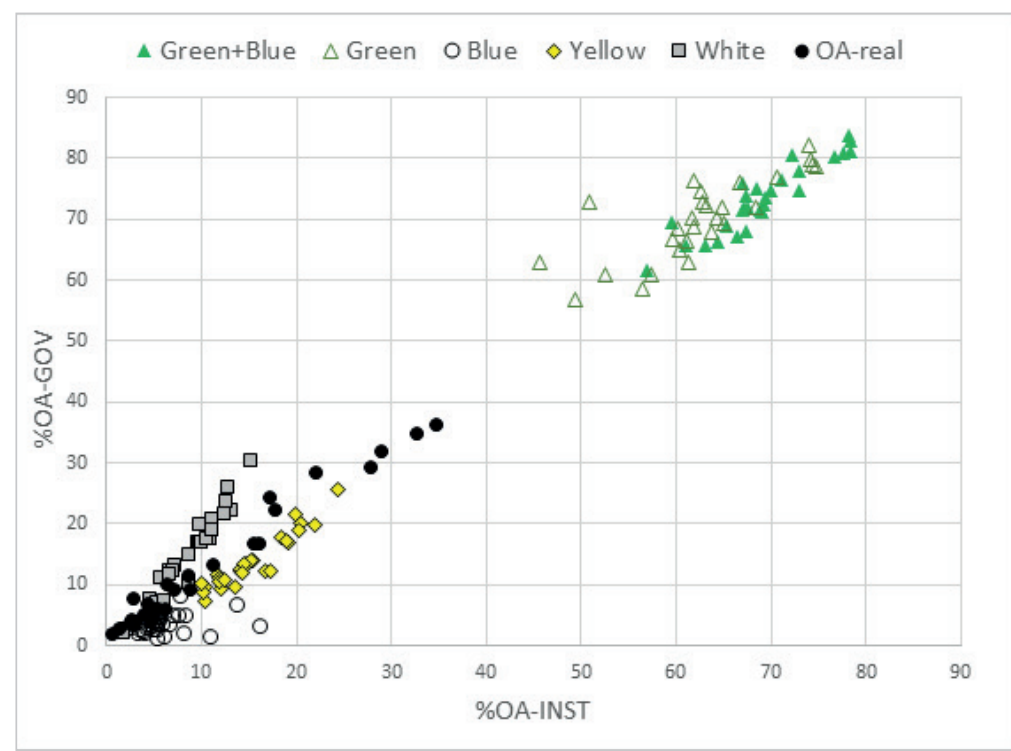

Figure 6. Percentage of real and potential open access (for INST and GOV) according to the color of the journal in which the articles were published based on the Sherpa/Romeo taxonomy (green, blue, yellow, white). 
In view of the results, it is clear that a policy is not sufficient to encourage archiving of scholarly outputs in institutional repositories, at least in the case studied. We therefore recommend:

- To monitor compliance with institutional policies and with the mandate of the Spanish Science law. This would allow scheduling actions to improve archiving and indirectly them to know the behaviour of their staff with regard to sharing their publications

- The funders that require OA to the publications arising from research projects should also establish mechanisms for monitoring compliance

- To take into account the works deposited in repositories for the assessment and promotion of Faculty staff, following the model of the University of Liège. This seems to be a good way to increase the participation of researchers

- To use current research information systems (CRISs) as source for the scholarly outputs metadata since they provide an accurate information about their publications. With this information libraries can establish a mechanism for asking the authors for the articles directly (this system was set up at Oregon State University, where the archiving of works indexed in the WoS between 2012 and 2014 rose from $12 \%$ to $45 \%$ )

- Facilitate and encourage self-archiving will help authors to meet their obligations to their employers and funders

- All authors of articles should keep a copy of the submitted version (pre-print) and the version accepted (post-print), because they may be able to use one of these if they are not allow to use the version of record.

Finally, we have not found any clear response why the compliance is lower than expected when institutions have their own policy plus the law mandate. Lack of awareness, inertia to the status quo, threat to infringe the copyright law, and lack of incentives or recognition of open access practices, might be part of the reasons. Authors are aware that during last 2 years the efforts of librarians and project managers have favoured self-archiving, however we should compare in future works if this perception corresponds with the real situation.

We recommend to monitor compliance with institutional policies and with the mandate of the Spanish Science law

\section{Acknowledgments}

The authors thank the Spanish Ministerio de Economía y Competitividad for funding the project CSO2014-52830-P, and the staff of the University of Bielefeld for allowing us to use the API of BASE.

\section{References}

Acceso Abierto (2016). Melibea. http://www.accesoabierto.net/politicas

Archambault, Éric; Amyot, Didier; Deschamps, Philipe; Nicol, Aurore; Rebout, Lise; Roberge, Guillaume (2013). Proportion of open access peer-reviewed papers at the Euro- pean and world levels - 2004-2011. Report for the European Commission by Science Metrix.

http://www.science-metrix.com/pdf/SM_EC_OA_ Availability_2004-2011.pdf

Bartol, Tomaz; Budimir, Gordana; Dekleva-Smrekar, Doris; Pusnik, Miro; Juznic, Primoz (2014). "Assessment of research fields in Scopus and Web of Science in the view of national research evaluation in Slovenia". Scientometrics, v. 98, pp. 1491-1504.

https://goo.gl/4SfK1k

https://doi.org/10.1007/s11192-013-1148-8

Bielefeld University Library (2016a). Bielefeld academic search engine (BASE).

https://www.base-search.net

Bielefeld University Library (2016b). BASE interface guide Version 1.10 (August 2016).

https://www.base-search.net/about/en/about_develop. php?menu=2

Björk, Bo-Christer; Welling, Patrik; Laakso, Mikael; Majlender, Peter; Hedlund, Turid; Guðnason, Guðni (2010). "Open access to the scientific journal literature: Situation 2009". PLoS one, v. 5, n. 6, pp. e11273.

https://doi.org/10.1371/journal.pone.0011273

BOAI (2002). Read the Budapest Open Access Initiative. http://www.budapestopenaccessinitiative.org/read

Borrego, Ángel (2016). “Measuring compliance with a Spanish government open access mandate". Journal of the Association for Information Science and Technology, v. 67, pp. 757-764.

https://doi.org/10.1002/asi.23422

Clarivate Analytics (2017). Web of Science Core Collection. http://wokinfo.com/products_tools/multidisciplinary/ webofscience

Chen, Xiaotian (2014). “Open access in 2013: reaching the $50 \%$ milestone". Serials review, v. 40, n. 1, pp. 21-27.

https://doi.org/10.1080/00987913.2014.895556

Eger, Thomas; Scheufen, Marc; Meierrieks, Daniel (2015). "The determinants of open access publishing: survey evidence from Germany". European journal of law and economics, v. 39, pp. 475-503.

https://doi.org/10.1007/s10657-015-9488-x

España (2011). “Ley 14/2011, de 1 de junio, de la ciencia, la tecnología y la innovación". BOE, n. 131, 2 junio.

https://www.boe.es/buscar/pdf/2011/BOE-A-2011-9617consolidado.pdf

European Commission (2011). Open access pilot in FP7. http://ec.europa.eu/research/science-society/document_ library/pdf_06/open-access-pilot_en.pdf

European Commission (2016). H2020 Programme. Guidelines on open access to scientific publications and research data in Horizon 2020.

https://ec.europa.eu/research/participants/data/ref/h2020/ grants_manual/hi/oa_pilot/h2020-hi-oa-pilot-guide_en.pdf

European Research Council (2007). ERC Scientific council 
guidelines for open access.

http://erc.europa.eu/sites/default/files/document/file/erc_ scc_guidelines_open_access.pdf

Fecyt (2014). Recommendations for the implementation of article 37 of the Spanish science, technology and innovation act: Open access dissemination.

http://recolecta.fecyt.es/sites/default/files/contenido/ documentos/Implantacion_Art37_AccesoAbierto_INGLES.pdf

Frass, Will; Cross, Jo; Gardner, Victoria (2014). Taylor \& Francis. Open access survey June 2014.

http://www.tandf.co.uk/journals/explore/open-accesssurvey-june2014.pdf

Gutknecht, Christian; Graf, Regula; Kissling, Ingrid; Krämer, Daniel; Milzow; Perini, Lionel; Würth, Stéphanie; Zimmermann, Thomas (2016). Open access to publications. SNSF monitoring report 2013-2015.

https://goo.gl/7JVLbu

Harnard, Stevan (2015). "Optimizing open access policy". The serials librarian, v. 69, n. 2, pp. 133-141.

https://doi.org/10.1080/0361526X.2015.1076368

Harvard University (2008). Harvard Faculty of Arts and Sciences Open Access Policy.

http://osc.hul.harvard.edu/hfaspolicy

Higher Education Funding Council for England (2014). Policy for open access in the post-2014 Research Excellence Framework: Updated July 2015.

http://www.hefce.ac.uk/pubs/year/2014/201407

Iuene (2016). Universities' yearly scientific output per professor.

http://www.iune.es/en_US/scientific-activity/publicationsper-professor

Jubb, Michael; Goldstein, Stephane; Amin, Mayur; Plume, Andrew; Aisati, M'Hamed; Oeben, Stephanie; Bath, Peter; Salter, Jennifer; Johnson, Rob; Fosci, Mattia (2015). Monitoring the transition to open access: A report for Universities UK.

https://www.acu.ac.uk/research-information-network/ monitoring-transition-to-open-access

Khabsa, Madian; Giles, C. Lee (2014). "The number of scholarly documents on the public Web". PLoS one, v. 9, n. 5, pp. e93949.

https://doi.org/10.1371/journal.pone.0093949

López-Illescas, Carmen; De-Moya-Anegón, Félix; Moed, Henk F. (2008). "Coverage and citation impact of oncological journals in the Web of Science and Scopus". Journal of informetrics, v. 2, pp. 304-316.

https://doi.org/10.1016/j.joi.2008.08.001

Massachusetts Institute of Technology (2009). MIT Faculty open access policy.

https://libraries.mit.edu/scholarly/mit-open-access/openaccess-policy

Mineco (2013). Plan estatal de investigación científica, técnica y de innovación 2013-2016.

http://www.idi.mineco.gob.es/stfls/MICINN/Investigacion/ FICHEROS/Plan_Estatal_Inves_cientifica_tecnica_innovacion.pdf
Mineco (2017). Plan estatal de investigación científica, técnica y de innovación 2017-2020.

http://www.idi.mineco.gob.es/stfls/MICINN/Prensa/ FICHEROS/2018/PlanEstatalIDI.pdf

NIH (2008). NIH public access policy details. National Institutes of Health.

http://publicaccess.nih.gov/policy.htm

NSF (2015). Today's data, tomorrow's discoveries. Increasing access to the results of research funded by the National Science Foundation.

http://www.nsf.gov/pubs/2015/nsf15052/nsf15052.pdf

Open access at the Max Planck Society (2003). Berlin declaration on open access to knowledge in the sciences and humanities.

https://openaccess.mpg.de/Berlin-Declaration

OpenAIRE (2015). OpenAIRE guidelines for literature repositories. https://guidelines.OpenAIRE.eu/en/latest/literature/index. html

OpenAIRE (2016a). FP7 statistics.

https://www.OpenAIRE.eu/fp7-stats

OpenAIRE (2016b). EGI - European Grid Initiative.

https://www.OpenAIRE.eu/egi-stats

Picarra, Mafalda (2015). Monitoring compliance with open access policies.

http://www.pasteur4oa.eu/sites/pasteur4oa/files/resource/ Brief_Monitoring\%20compliance\%20with\%200A\%20 policies_0.pdf

Research Councils UK (2014). RCUK policy on open access. https://www.ukri.org/funding/information-for-awardholders/open-access/open-access-policy

Ribeiro, Lígia; De-Castro, Pablo; Mennielli, Michele (2016). Final report: Eunis - Eurocris joint survey on CRIS and IR. ERAI (Eunis Research and Analysis Initiative).

http://www.eunis.org/wp-content/uploads/2016/03/crisreport-ED.pdf

Ruiz-Pérez, Rafael; Delgado-López-Cózar, Emilio (2013). "Internacionalización de la Revista Española de Sanidad Penitenciaria de Medline a Web of Science". Revista española de sanidad penitenciaria, v. 15, n. 2, pp. 39-43.

http://www.sanipe.es/OJS/index.php/RESP/article/view/331/751

Ruiz-Pérez, Rafael; Delgado-López-Cózar, Emilio; Jiménez-Contreras, Evaristo (2006). "Criterios del Institute for Scientific Information para la selección de revistas científicas. Su aplicación a las revistas españolas: Metodología e indicadores". International journal of clinical and health psychology, v. 6, n. 2, pp. 401-424. http://www.redalyc.org/pdf/337/33760211.pdf

Sale, Arthur (2006). The acquisition of open access research articles.

https://goo.gl/wvuUND

Sherpa/Romeo (2016a). RoMEO colours. https://goo.gl/UKnxbe

Sherpa/Romeo (2016b). Application programmers' interface. http://www.sherpa.ac.uk/romeo/apimanual.php?la=en 
Shieber, Stuart; Suber, Peter (2015). Good practices for university open-access policies.

https://goo.gl/NiA9cR

Spezi, Valérie; Fry, Jenny; Creaser, Claire; Probets, Steve; White, Sonya (2013). "Researchers' green open access practice: A cross disciplinary analysis". Journal of documentation, v. 69, n. 3, pp. 334-359.

https://doi.org/10.1108/jd-01-2012-0008

Suber, Peter (2004). Open access overview.

http://legacy.earlham.edu/ peters/fos/overview.htm

Surfnet (2013). info-eu-repo - Standards - Collaboration Infrastructure Wiki.

https://goo.gl/wbt8vf
Swan, Alma; Gargouri, Yassine; Hunt, Megan; Harnad, Stevan (2015). Open access oolicy: Numbers, analysis, effectiveness. Pasteur4OA Work Package 3 report: Open Access policies.

http://eprints.soton.ac.uk/375854

Universidade do Minho (2005). Politica de auto-arquivo de publicações.

https://goo.gl/xRHt2L

University of Liège (2007). "Open Access": mise en oeuvre au sein de l'Université de Liège.

http://orbi.ulg.ac.be/files/extrait_moniteur_CA.pdf

Wellcome Trust (2005). Open access policy.

http://www.wellcome.ac.uk/doc_WTD002766.html

\section{Appendix 1}

\begin{tabular}{|c|c|}
\hline University & Set search in ADDRESS Field (AD) \\
\hline CEU & $\begin{array}{l}\text { "CEU Card?nal Herrera" OR "Card?nal Herrera CEU” OR “Univ* Card?nal Herrera" OR "Card?nal Herrera Univ*” OR UCH-CEU OR CEU- } \\
\text { UCH OR UCHCEU OR CEUUCH OR “San Pablo CEU Univ*" OR “Univ* San Pablo CEU" OR "CEU San Pablo Univ*" OR “Univ* CEU San } \\
\text { Pablo" OR CEU-USP OR USP-CEU OR CEUUSP OR USPCEU }\end{array}$ \\
\hline$U A$ & "Univ* Al?cant*" OR "Univ* de Al?cant*"OR "Al?cant* Univ*"OR “Univ* of Al?cant*" OR "Univ**Al?cant*" \\
\hline$U A B$ & "Univ* Auto* Barcelona" OR "Auto* Univ* Barcelona" OR UAB \\
\hline$U A H$ & "Univ* Alcala" OR UAH \\
\hline UAM & "Univ* Auto* Madrid" OR "Univ* Auto* de Madrid" OR "Auto* Univ* Madrid" OR "Auto* Univ* of Madrid" \\
\hline$U B$ & "Univ* Barcelona" OR UB \\
\hline$U B U$ & "Univ* Burgos" OR UBU \\
\hline UC3M & "Univ* Carlos III" OR UC3M \\
\hline UCM & "Univ* Compluten*" OR "Compluten* Univ* Madrid" OR UCM \\
\hline UdG & "Univ* Gerona" OR “Univ* Girona" OR UdG \\
\hline$U d L$ & "Univ* Lleida" OR “Univ* Lerida" OR UdL \\
\hline$U H U$ & "Univ* Huelva" OR UHU \\
\hline ונU & “Univ* Jaume" OR"Jaume Univ*” OR "Jaume I Univ*" OR UJ (NOT Kyoto) \\
\hline ULPGC & $\begin{array}{l}\text { "Univ* Palmas Gran Canaria" OR “Univ* Las Palmas de Gran Canaria" OR “Univ* Las Palmas Gran Canaria" OR “Univ* Palmas de Gran } \\
\text { Canaria" OR "Palmas Gran Canaria Univ*" OR "Las Palmas de Gran Canaria Univ*" OR "Las Palmas Gran Canaria Univ*" OR "Palmas de } \\
\text { Gran Canaria Univ*" OR ULPGC }\end{array}$ \\
\hline UNED & "Univ* Nac* Educ* Distan*"OR "Nat* Distan* Educ* Univ*" OR UNED \\
\hline UNICAN & "Univ* Cantabria" OR UNICAN \\
\hline UOC & "Univ* Oberta Cat*" OR “Univ* Abierta Cat*" OR “Open Univ* Cat*" OR (UOC NEAR/1 Spain) \\
\hline UPC & "Univ* Politec* Cat*" OR "Polytech* Univ* Cat*"OR"Tech* Univ* Cat*" OR UPC \\
\hline$U P C T$ & "Univ* Politec* Cartagena" OR "Polytech* Univ* Cartagena" OR "Tech* Univ* Cartagena" OR UPCT \\
\hline UPF & "Univ* Pompeu Fabra" OR "Pompeu Fabra Univ*" OR UPF \\
\hline UPM & "Univ* Politec* Madrid" OR “Polytech* Univ* Madrid" OR “Tech* Univ* Madrid" OR UPM (NOT Malaysia) \\
\hline UPNA & "Univ* Publ* de Navarra" OR "Univ* Publ* Navarra" OR "Nafarroako Unib* Publ*" OR "Publ* Univ* of Navarra" OR "Publ* Univ* Navarra" \\
\hline UPO & "Univ* Pabl* de Olavide" OR “Univ* Pabl* of Olavide" OR "Pabl* de Olvaide Univ*" OR "Pabl* Olvaide Univ*" \\
\hline UPV & "Univ* Politec* Valencia" OR "Tech* Univ* Valencia" OR"Polytech* Univ* Valencia" \\
\hline UPV/EHU & $\begin{array}{l}\text { "Univ* of Basq* Count*" OR "Univ* Basq* Count*" OR"Basq* Count* Univ*" OR "Univ* Pais Vasc*" OR "Univ* del Pais Vasc" OR "Pais } \\
\text { Vasc* Univ*" OR "Eus* Herri* Uniber*" OR "UPV/EHU" }\end{array}$ \\
\hline URJC & "Univ* Rey Juan Carlos" OR "King Juan Carlos Univ*" OR URJC \\
\hline UV & "Univ* of Valencia" OR"Univ* Valencia" OR “Valencia Univ*" OR“"Univ* de Valencia” \\
\hline UVIC-UCC & "Univ* Vic" OR "Univ* Central Cat*" OR "Central Univ* Cat*" OR UVIC OR UVIC-UCC OR UCC-UVIC \\
\hline
\end{tabular}




\section{Glossary}

\begin{tabular}{|c|c|}
\hline Acronym & Spelled out \\
\hline BASE & Bielefeld Academic Search Engine \\
\hline Sherpa/Romeo & Database that shows the copyright and open access self-archiving policies of academic journals \\
\hline WoS & Web of Science database \\
\hline CRIS & Current research information system \\
\hline PEER project & Publishing and the Ecology of European Research project \\
\hline $7 F P$ & Seventh Framework Program of European Union \\
\hline STEM & Science, technology, engineering and mathematics \\
\hline H2O2O & Horizon 2020 program of the European Commission \\
\hline FCT & Fundação para a Ciência e a Tecnologia, Portugal \\
\hline SNSF & Schweizerischer Nationalfonds or in English Swiss National Science Foundation \\
\hline DOI & Digital object identifier \\
\hline DOAJ & Directory of open access journals \\
\hline Pasteur4OA project & Open access policy alignment strategies for European Union research project \\
\hline API & Application programming interface \\
\hline XML & Extensible markup language \\
\hline WoSCC & Web of Science Core Collection databases \\
\hline DC & Dublin core schema of metadata \\
\hline URI & Uniform resource identifier \\
\hline URL & Uniform resource locator \\
\hline OG & Label of organization field in WoSCC \\
\hline AD & Label of address field in WoSCC \\
\hline FO & Label of funding agency field in WoSCC \\
\hline FG & Label of grant number field in WoSCC \\
\hline FT & Label of funding text field in WoSCC \\
\hline Mineco & Spanish Ministry of Economy and Competitiveness \\
\hline MEC & Spanish Ministry of Economy and Competitiveness \\
\hline Mincinn & Spanish Ministry of Science and Innovation \\
\hline CSIC & Spanish High Scientific Research Council \\
\hline Isciii & Spanish Carlos III Health Institute \\
\hline Cicyt & Spanish Comisión Interministerial de Ciencia y Tecnología \\
\hline Fecyt & Spanish Fundación Española para la Ciencia y la Tecnología \\
\hline FIS & Spanish Fondo de Investigacion Sanitaria \\
\hline INIA & Spanish Instituto Nacional de Investigación y Tecnología Agraria y Alimentaria \\
\hline Micinn & Spanish Ministry of Science and Innovation \\
\hline $\mathrm{ICl}$ & Institutional compliance index \\
\hline $\mathrm{GCl}$ & Governmental compliance index \\
\hline PAI & Potential self-archiving index \\
\hline IUNE & Obervatorio de la Actividad Investigadora en la Universidad Española (http://www.iune.es) \\
\hline INST & Institutional (University) \\
\hline GOV & Government bodies \\
\hline
\end{tabular}

